\title{
9 Publications of fellows and staff
}

\section{Ando, Clifford}

- 2013: „Subjects, gods and empire, or Monarchism as a theological problem“, in: Jörg Rüpke (ed.), The Individual in the Religions of the Ancient Mediterranean, Oxford: Oxford University Press, 86-111.

- 2014: „Postscript: Cities, citizenship and the work of empire“, in: Claudia Rapp and H. A. Drake, (eds.), The city in the classical and post-classical world. Changing contexts of power and identity. Cambridge: Cambridge University Press, 240-256.

- 2015: „Three revolutions in government“, in: Lucian Reinfandt, Stephan Prochazka and Sven Tost, (eds.), Official epistolography and the languages of power, Vienna: Verlag der Österreichischen Akademie der Wissenschaften, 163-172.

- 2016: „The rites of others“, in: Jonathan Edmondson and Alison Keith (eds.), Roman Literary Cultures: Domestic Politics, Revolutionary Poetics, Civic Spectacles. Toronto/Buffalo/London: University of Toronto Press, 254-277.

- 2016: „Religiöse und politische Zugehörigkeit von Caracalla bis Theodosius.“ Translated by Leif Scheuermann. Keryx - Zeitschrift für Antike 4 (2016), 61-73.

\section{Arnhold, Marlis}

- 2020: „Transformationen stadtrömischer Heiligtümer während der späten Republik und Kaiserzeit“. Contextualizing the Sacred. Turnhout: Brepols.

-; Harry O. Maier, Jörg Rüpke (eds.) 2019: „Seeing the god: image, space, performance and vision in the religion of the Roman Empire“. Tübingen: Mohr Siebeck.

- 2013: „Group Settings and Religious Experiences“, in: Cusumano, N. et al. (eds.), Memory and Religious Experience in the Greco-Roman World. Stuttgart: Steiner, 145-165.

- 2015: „Male Worshippers and the Cult of Bona Dea“, Religion in the Roman Empire 1.1, 51-70.

- 2015: „Sanctuaries and Urban Spatial Settings in Roman Imperial Ostia“, in: Rüpke, J.; Raja, R. (eds.), A Companion to the Archaeology of Religion in the Ancient World. Malden, MA: John Wiley \& Sons.

- 2016: (together with Jörg Rüpke) „Appropriating and shaping religious practices in the Roman Republic“, in: Haake, Matthias; Harders, Ann-Cathrin (eds.), Politische Kultur und soziale Struktur im Republikanischen Rom. Steiner: Stuttgart, 416-432.

- 2018: „Republikanische Heiligtümer im kaiserzeitlichen Rom“, in: Blömer, Michael; Eckhardt, Benedikt (eds.), Transformationen paganer Religion in der Kaiserzeit. Rahmenbedingungen und Konzepte, RGVV vol. 72, Berlin: de Gruyter, 175-198.

- 2019: „Imagining Mithras in light of iconographic standardization and individual accentuation“, in: Arnhold, Marlis; Maier, Harry 0.; Rüpke, Jörg (eds.), Seeing the god: image, space, performance and vision in the religion of the Roman Empire. Tübingen: Mohr Siebeck, 125-147.

\section{Banerjee-Dube, Ishita}

- 2019: Religious individualisation and collective bhakti: Sarala Dasa and Bhima Bhoi, in: Martin Fuchs et al. (eds.), Religious Individualisation: Historical Dimensions and Comparative Perspectives, Berlin: de Gruyter, 847-864. 


\section{Bashir, Shahzad}

- 2019: Reading the self in Persian prose and poetry, in: Martin Fuchs et al. (eds.), Religious Individualisation: Historical Dimensions and Comparative Perspectives, Berlin: de Gruyter, 443-458.

\section{Becker, Eve-Marie}

- 2017. The Birth of Christian History: Memory and Time from Mark to Luke-Acts. New Haven: Yale University Press.

- 2015: „Historiography: II. Greco-Roman Antiquity“, Encyclopedia of the Bible and Its Reception vol. 11. Berlin/Boston: de Gruyter. 1129-1135.

- 2016: „Shaping Identity by Writing History: Earliest Christianity in its Making“, Religion in the Roman Empire 2, 2. 152-169.

\section{Ben-Tov, Asaph}

2019: Early modern erudition and religious individualisation: the case of Johann Zechendorff (15801662), in: Martin Fuchs et al. (eds.), Religious Individualisation: Historical Dimensions and Comparative Perspectives, Berlin: de Gruyter, 1255-1268.

\section{Ben-Zaken, Avner}

- 2017: „No Place for Regrets: Heidegger and Thomas of Erfurt“, Haaretz Literary Supplement, 28.12.2017 (in Hebrew).

- 2019: „Traveling with the Picatrix: On the Cultural Liminalities of Science and Magic“, in: Martin Fuchs et al. (eds.), Religious Individualisation: Historical Dimensions and Comparative Perspectives, Berlin: de Gruyter, 1033-1064.

\section{Boyarin, Daniel}

- 2018. Judaism: the genealogy of a modern notion, Key Words in Jewish Studies, New Brunswick N): Rutgers University Press.

\section{Bremmer, Jan}

- 2014. Initiation into the Mysteries of the Ancient World, Hardback and ebook: Berlin and Boston: de Gruyter.

-; Boschung, Dietrich (eds.) 2015. The Materiality of Magic, Munich: Wilhelm Fink.

- et al. (eds.) 2016. The Ascension of Isaiah, Leuven: Peeters.

- 2017. Maidens, Magic and Martyrs in Early Christianity: Collected Essays I, Tübingen: Mohr Siebeck.

- 2014: Religious Violence between Greeks, Romans, Christians and Jews, in: A.-K. Geljon and R. Roukema (eds), Violence in Early Christianity: Victims and Perpetrators, Leiden: Brill, 8-30. 
- 2014: Conversion in the Oldest Apocryphal Acts, in: B.S. Bøgh (ed.), Conversion and Initiation in

Antiquity: shifting identities - creating change, Bern: Peter Lang, 59-76.

- 2015: Preface: The Materiality of Magic, in: J. Bremmer and D. Boschung (eds.), The Materiality of

Magic, Munich: Wilhelm Fink, 7-19.

- 2015: From Books with Magic to Magical Books in Ancient Greece and Rome, in: D. Boschung and

J. Bremmer (eds.), The Materiality of Magic, Munich: Wilhelm Fink, 241-269.

- 2015: God against the Gods: Early Christians and the Worship of Statues, in: D. Boschung and

A. Schaefer (eds), Götterbilder der mittleren und späten Kaiserzeit, Munich: Wilhelm Fink, 139-58.

- 2015: The Passion of Perpetua und Felicitas, Reallexikon für Antike und Christentum, vol. 27, Lief. 211, 178-190.

- 2016: The Domestication of Early Christian Prophecy and the Ascension of Isaiah, in: J. Bremmer et al. (eds.), The Ascension of Isaiah, Leuven: Peeters, 1-23.

- 2016: Shamanism in Classical Scholarship: where are we now?, in P. Jackson (ed.), Horizons of Shamanism: A Triangular Approach: Stockholm Studies in Comparative Religion 35, Stockholm, 52-78.

- 2016: Ancient Necromancy: Fact or Fiction?, in: K. Bielawski (ed.), Mantic Perspectives - oracles, prophecy and performance, Gardzienice, Warsaw, Lublin: Ośrodek Praktyk Teatralnych 'Gardzienice', 119-141.

- 2016: Body Politics: Imagining Human Sacrifice in Euripides’ Iphigeneia in Aulis, in: K. Bielawski

(ed.), Mantic Perspectives - oracles, prophecy and performance, Gardzienice, Warsaw, Lublin:

Ośrodek Praktyk Teatralnych 'Gardzienice', 35-56.

- 2016: The Construction of an Individual Eschatology: the Case of the Orphic Gold Leaves, in: K.

Waldner et al. (eds), Burial Rituals, Ideas of Afterlife, and the Individual in the Hellenistic World and the Roman Empire, Stuttgart: Steiner, 31-52.

- 2016: Arthur Darby Nock's Conversion (1933): a balance, in: J. Weitbrecht, W. Röcke and R. von

Bernuth (eds), Zwischen Ereignis und Erzählung. Konversion als Medium der Selbstbeschreibung in Mittelalter und Früher Neuzeit, Berlin/Boston: de Gruyter, 9-29.

- 2016: Richard Reitzenstein, Pythagoras and the Life of Antony, in: A.-B. Renger and A. Stavru

(eds), Forms and Transformations of Pythagorean Knowledge, Wiesbaden: Harassowitz,

227-245.

- 2016: Theseus' and Peirithoos' Descent into the Underworld, Les Études Classiques 83, 35-49.

- 2016: Imperial Mysteries, Mètis 14, 21-34.

- 2017: Lucian on Peregrinus and Alexander of Abonuteichos: A Sceptical View of Two Religious Entrepeneurs, in: R.L. Gordon et al. (eds), Beyond Priesthood: Religious Entrepreneurs and Innovators in the Roman Empire, Berlin and Boston: de Gruyter, 47-76.

- 2017: Philosophy and the Mysteries, in: C. Riedweg (ed.), PHILOSOPHIA in der Konkurrenz von Schulen, Wissenschaften und Religionen. Zur Pluralisierung des Philosophiebegriffs in Kaiserzeit und Spätantike, Berlin/Boston: de Gruyter, 99-126.

- 2017: Cult Spaces in a Longue Durée Perspective, in: H.-U. Wiemer (ed.), Kulträume. Studien zum Verhältnis von Kult und Raum in alten Kulturen. Stuttgart: Steiner, 285-296.

- 2017: Pilgrimage Progress?, in: T.M. Kristensen and W. Friese (eds), Excavating Pilgrimage, Abingdon and New York: Routledge, 275-284.

-; van der Lans, Birgit 2018: Tacitus and the Persecution of the Christians: An Invention of Tradition?, Eirene 53, 299-231.

- 2018: Jews, Pagans and Christians in the Apocryphal Acts, in: St. Alkier and H. Leppin (eds), Juden - Heiden - Christen? Tübingen: Mohr Siebeck, 333-362. 
- 2018: Religious Violence and its Roots. A View from Antiquity, in: W. Mayer and C.L. de Wet (eds), Reconceiving Religious Conflict. New Views from the Formative Centuries of Christianity, Abingdon and New York, 30-42.

- 2018: Review: Jörg Rüpke’s Pantheon, Munich: Beck, 2016, in Religion in the Roman Empire 4, 107-112.

- 2019: Religion and the limits of individualisation in ancient Athens: Andocides, Socrates, and the fair-breasted Phryne, in: Martin Fuchs et al. (eds.), Religious Individualisation: Historical Dimensions and Comparative Perspectives, Berlin: de Gruyter, 1009-1032.

\section{Bueno, Arthur}

- 2019: Simmel and the forms of in-dividuality, in: Martin Fuchs et al. (eds.), Religious Individualisation: Historical Dimensions and Comparative Perspectives, Berlin: de Gruyter, 409-436.

\section{Casteigt, Julie}

- Forthcoming. Métaphysique et connaissance testimoniale. Une lecture figurale du Super lohannem (In 1, 7) d'Albert le Grand, Leuven: Peeters, (Eckhart: Texts and Studies 11).

- 2019. Albertus Magnus, Super Iohannem (Ioh. 1, 1-18), Leuven: Peeters, (Eckhart: Texts and Studies 10).

- (ed.) 2019. Verbe et chair: le sens de l'union dans la réception philosophique de l'Évangile de Jean (In 1, 12-14), Münster, Berlin, Wien, Zürich and London: LIT Verlag, (Théologie biblique).

- 2013: „Au-delà du sujet, l'impersonnel?“, Archives de Philosophie, Cahier n. 76/3, automne 2013, 371-374.

- 2013: „Comment passer de l'ignorance à la connaissance? Une figure du maître manuductor selon Albert le Grand“, in: Noacco, C./Bonnet, C./Marot, P./Orfanos, Ch. (eds.), Figures du maître, (Interférences), Rennes: PUR, 45-59.

- 2013: „Deux exemples de rencontres entre philosophes juifs, musulmans et chrétiens: Thomas d'Aquin/ Averroès et Maître Eckhart/Maïmonide“, in: Controverses religieuses au Moyen Âge et enjeux contemporains - autour de Ramon Llull, Maïmonide, Averroès, Thomas d'Aquin, Centre théologique Ramon Llull de Perpignan, Diocèse de Perpignan, colloque des 5-6 octobre 2007, Girona: Gràfiques Alzamora, 63-92.

- 2013: „Le De anima dans l'Expositio sancti Evangelii secundum lohannem de Maître Eckhart: une révolution aristotélicienne dans la noétique eckhartienne?“, in: Friedman, R./Counet, J.-M. (eds.), Medieval Perspectives on Aristotle's De Anima, Institut Supérieur de Philosophie, Louvain-la-Neuve/Leuven: Peeters, 121-144.

- 2013: „Ni Conrad, ni Henri’: le fond de la personne est-il personnel, impersonnel ou sans fond dans les sermons allemands de Maître Eckhart?“, Archives de Philosophie, Cahier n. 76/3 (automne 2013), 425-440.

- 2014: „Coexistence et médiation dans le Prologue de l'Évangile selon saint Jean commenté par Albert le Grand“ in: Musco, A./Musotto, G. (eds.), Coesistenza e Cooperazione nel Medioevo. Coexistence and Cooperation in the Middle Ages. In Memoriam Leonardo E. Boyle (1923-1999). IV European Congress of Medieval Studies F.I.D.E.M. (Fédération Internationale des Instituts d’Études Médiévales), Palermo, 23-37 june 2009, Palermo: Officina di Studi Medievali, 1-24. 
- 2014: „Quelques propositions synthétiques pour une lecture des interprétations albertienne et eckhartienne de Jn 1, 6-8“', in: Amerini, F. (ed.), 'In Principio erat Verbum'. Philosophy and Theology in the Commentaries of the Gospel of John (II-XIV Century), Archa Verbi. Subsidia, vol. 11, Münster: Aschendorff Verlag, 159-176.

- 2015: „Condamnés à une connaissance de chauve-souris? Albert le Grand et l'intellect humain conjoint aux sens et à l'imagination“, in: Bouchet, Fl./Klinger-Dollé, A.-H. (eds.), Penser les cinq sens au Moyen Âge: poétique, esthétique, éthique, (Rencontres, Civilisation médiévale), Paris: éditions Classiques Garnier, 37-54.

- 2015: „Contre une idée reçue selon laquelle Maître Eckhart ne parle pas d'amour...“, Recherches philosophiques 1 (septembre 2015), 31-56.

- 2015: „Le principe est-il indétermination ou principe de différenciation selon le commentaire eckhartien de l'Évangile de Jean? ,, in: J.-Ch. Lemaître \& É. Rigal, Jean-Marie Vaysse - Cartographies de le pensée à la fin de la métaphysique, (Europaea Memoria), Hildesheim: Olms, 199-216.

-; avec Dietmar Mieth et Jörg Rüpke 2016: „Der Träger der Erfurter Riesenthorarolle. Eine religionsgeschichtliche Hypothese zu einem übersehenen Judaicum, Zeitschrift für Religion und Geistesgeschichte 68/2 (Mai 2016), 97-118.

- 2016: „Énonciation et indétermination. Au-delà de la lecture derridienne de la théologie négative de Maître Eckhart?“, Ephemerides Theologicae Lovanienses 92/2 (2016), 229-250.

- 2016: „Le lieu, principe d'individualisation ou d'intériorité réciproque dans le commentaire johannique de Maître Eckhart?“, in: Ch. Wojtulewicz, J. Vinzent (eds.), Performing Bodies. Time and Space in Meister Eckhart and in the Performances and Video Installations of Taery Kim, (Eckhart: Texts and Studies 6), Leuven: Peeters Publishers, 115-141.

- 2016: „Welcher individuelle Erkenntnisweg zum Göttlichen ist für den Menschen nach Albert dem Großen möglich“, Theologische Quartalschrift, n.196, Heft 3/2016, 249-275

- 2017: „Aimer l'un dans l'autre ou d'un désordre amoureux condamné: une lecture de l'article 25 de la bulle pontificale In agro dominico", in: D.Mieth, M-A. Vannier, M. Vinzent and C.M. Wojtulewicz (eds.), Meister Eckhart in Paris and Strasbourg, (Eckhart: Texts and Studies 4), Leuven: Peeters, 177-208.

- 2017: „Identité du témoin et accomplissement des figures: le modèle de la voix et du Verbe dans la lecture albertienne de Jn 1, 19-24“, Annali di Storia dell'Esegesi 34/1 (2017), 125-144.

- 2017: „La fonction des médiations matérielles dans l'acte baptismal: Entre discours exégétique (Super Iohannem, Jn 1, 25-28) et discours théologique chez Albert le Grand“, in: J. Casteigt (ed.), Le Témoin dans la tradition johannique, Revue de sciences philosophiques et théologiques101 (2017/1), 69-92.

- 2017: „Le Témoin dans la tradition johannique“, Revue de sciences philosophiques et théologiques $101(2017 / 1)$

- 2017: „Malum bonum et lucem tenebras. Die göttliche Bestimmung des menschlichen Seins und Handelns in der Auseinandersetzung der Avignoneser Theologenkommission mit Meister Eckhart“, Theologische Quartalschrift, n.197, Heft 1/2017, 72-95.

- 2018: „Metaphysics and testimonial knowledge in the Super lohannem of Albert the Great“, Traditio 73, 255-289.

- 2018: „'Soleil noir‘. La théologie négative de Maître Eckhart jugée malsonnante dans l'article 5 du Votum Avenionense“, in: Rodolphe Calin, Tobias Dangel und Roberto Vinco (Hrsg.), Die Tradition der negativen Theologie in der deutschen und französischen Philosophie, Universitätsverlag Winter, Heidelberg, (Heidelberger Forschungen 41), 67-90.

- 2018: „Incarnation et témoignage: l'économie des médiations dans le commentaire du Prologue de l'Évangile de Jean par Albert le Grand“", in: J. Casteigt (éd.), Verbe et chair: le sens de l'union 
dans la réception philosophique de l'Évangile de Jean (ln 1, 12-14), Münster, Berlin, Wien, Zürich and London: LIT Verlag, 75-106.

- 2019: „'Vase of light': from the exceptional individuality to the individualisation process as influenced by Greek-Arabic cosmology in Albert the Great's Super lohannem“, in: Martin Fuchs et al. (eds.), Religious Individualisation: Historical Dimensions and Comparative Perspectives. Berlin: de Gruyter, 53-72.

- 2019: „The subject as totum potestativum in Albert the Great's Æuvre: cultural transfer and relational identity“, in: Martin Fuchs et al. (eds.), Religious Individualisation: Historical Dimensions and Comparative Perspectives, Berlin: de Gruyter, 347-362.

- 2020: „Selbstbestimmung vor dem religiösen Gesetz: die Auseinandersetzung Meister Eckharts mit der Avignoneser Kommission“, in: D. Mieth (Hrsg.), Religiöse Selbstbestimmung - die Anfänge im Mittelalter und das Konzept Meister Eckharts, Beiheft des Meister Eckhart Jahrbuches, Aschendorff: Kohlhammer.

\section{Conolly, John}

- 2016: „Eckhart and the Will of God: A Reply to Stump“, Medieval Mystical Theology, 25, 1, May 2016, 6-20.

- 2017: „Tatort Garten Eden: Eigennutz und Individualisierung in der Ursündenlehre Meister Eckharts“, Theologische Quartalschrift, 197, 1 (2017), 48-71.

- 2018: „Freiheit und Wille bei Eckhart und Kant“, Meister-Eckhart-Jahrbuch 12, Spring 2018, $293-$ 318.

- 2019: „,Von den guten wercken“: Eckhart und Luther über die Werkgerechtigkeit und die rechte Motivation als ,Springbrunnen "“ under review for publication in the Meister-Eckhart-Jahrbuch 13, Spring 2019.

- 2016: „Book Review of Kurt Flasch, Meister Eckhart: Philosopher of Christianity“,in: The Catholic Historical Review, Fall 2016, Vol. 102, No. 4, 831-32.

\section{Dalmia, Vasudha}

2019: Being Hindu in India: culture, religion, and the Gita Press (1950), in Martin Fuchs et al. (eds.), Religious Individualisation: Historical Dimensions and Comparative Perspectives, Berlin: de Gruyter, 1097-1120.

\section{Deeg, Max}

- 2019: Many biographies - multiple individualities: the identities of the Chinese Buddhist monk Xuanzang, in: Martin Fuchs et al. (eds.), Religious Individualisation: Historical Dimensions and Comparative Perspectives, Berlin: de Gruyter, 913-938.

\section{Deuser, Hermann}

-; Saskia Wendel (eds.) 2012. Dialektik der Freiheit, Tübingen: Mohr Siebeck.

-; Markus Kleinert, Magnus Schlette (eds.) 2015. Metamorphosen des Heiligen, Religion und Aufklärung 25, Tübingen: Mohr Siebeck.

- 2013: „Marvels, Miracles, Signs and the Real. Peirce’s Semiotics in Religion and Art“, in: Stefan Alkier/Annette Weissenrieder (eds.), Miracles Revisited, Berlin/Boston: de Gruyter, 377-390. 
- 2016: „Theology of Nature“, in: Holy Light Theological Journal, Taiwan, No. 1, December 2016, 13-53.

\section{Dey, Amit}

- 2019: Islamic mystical responses to hegemonic orthodoxy: the subcontinental perspective, in: Martin Fuchs et al. (eds.), Religious Individualisation: Historical Dimensions and Comparative Perspectives, Berlin: de Gruyter, 1269-1290.

\section{Dube, Saurabh}

- 2019: Subjects of conversion in colonial central India, in: Martin Fuchs et al. (eds.), Religious Individualisation: Historical Dimensions and Comparative Perspectives, Berlin: de Gruyter, 895-912.

\section{Dureau, Christine}

- 2019: 'Greater love ...’: Methodist missionaries, self-sacrifice and relational personhood, in: Martin Fuchs et al. (eds.), Religious Individualisation: Historical Dimensions and Comparative Perspectives, Berlin: de Gruyter, 583-602.

\section{Eidinow, Esther}

- 2019: Self as other: distanciation and reflexivity in ancient Greek divination, in: Martin Fuchs et al. (eds.), Religious Individualisation: Historical Dimensions and Comparative Perspectives, Berlin: de Gruyter, 541-558.

\section{Engmann, Matthias}

- 2019: Taking Job as an example. Kierkegaard: traces of religious individualization, in: Martin Fuchs et al. (eds.), Religious Individualisation: Historical Dimensions and Comparative Perspectives, Berlin: de Gruyter, 159-184.

- 2019: Disunited identity. Kierkegaard: traces towards dividuality, in: Martin Fuchs et al. (eds.), Religious Individualisation: Historical Dimensions and Comparative Perspectives, Berlin: de Gruyter, 497-512.

\section{Facchini, Cristiana}

-; T. Catalan (eds.) 2015. „Portrait of Italian Jews (1800s-1930s)“ = Quest. Issues in Contemporary Jewish History 8 (2015).

-; Lannoy A. (eds.) 2019. The other Jesus. Alternative histories of Jesus and the religious world of the past from the nineteenth and early twentieth centuries, Brepols: Turnhout (collection of 12 articles \& introduction, forthcoming).

- 2013: „Voci ebraiche sulla tolleranza religiosa. Pratiche e teorie nella Venezia barocca“, Annali di storia dell'esegesi 2/30 (2013), 393-419. 
- 2014: „Orientalistica ed Ebraismo. Una storia ai margini. David Castelli e Giorgio Levi della Vida“, in: M. Mazza, N. Spineto, La storiografia storico-religiosa italiana tra la fine dell'800 e la seconda guerra mondiale, Alessandria: Edizioni dell'Orso, 111-139.

- 2014: „Predicare nel ghetto. Riflessioni su riti orali e performance rituale nel mondo ebraico di età barocca“, in: M. Del Bianco Cotrozzi, R. Di Segni, M. Massenzio (eds.), Non solo verso Oriente. Studi sull'ebraismo in onore di Pier Cesare loly Zorattini, Firenze: L.S. Olschki, 173-196.

- 2015: „Judaism. An Inquiry into the Historical Discourse“, in: B.-C. Otto, S. Rau, J. Rüpke (eds.), History and Religion: Narrating a Religious Past (Religionsgeschichtliche Versuche und Vorarbeiten 68), Berlin: De Gruyter, 371-392.

- 2015: „Six Authors in Search of a Narrative, in Portrait of Italian Jews (1800s-1930s)“, T. Catalan and C. Facchini (eds.), Quest Issues in Contemporary Jewish History 8 (2015), I-XX.

- 2016: „Luigi Luzzatti and the Oriental Front: Jewish Agency and the Politics of Religious Toleration", in: M. Dogo and T. Catalan (eds.), The Jews and the Nation-States of Southeastern Europe from the 19th Century to the Great Depression: Combining Viewpoints on a Controversial Story, Newcastle: Cambridge Scholars, 2016, 227-245.

- 2016: „Luigi Luzzatti e la teoria della tolleranza religiosa. Per una storia del consumo pubblico delle scienze delle religioni” Annali di storia dell'esegesi 33/1 (2016), 275-300.

- 2016: „Narrating, Visualizing, Performing, and Feeling a Religion. On representations of Judaism”, in Dynamics of Religion. Past and Present, edited by C. Bochinger, J. Rüpke together with Elisabeth Begemann (Religionsgeschichtliche Versuche und Vorarbeiten 67), Berlin: de Gruyter, 273-296.

- 2017: „Entangled histories. A road map to religious individualization in early modern Judaism“, Annali di storia dell'esegesi 34/1, 145-174.

- 2018: „Il Gesù di Leon Modena. Per una storia materiale ed urbana del Magen we-herev di Leon Modena", Annali di storia dell'esegesi 35/1 (2018), 163-187.

- 2018: „Living in Exile: Wissenschaft des Judentums and the study of religion in Italy (1890s1930s)" in: F. Bregoli, C. Ferrara degli Uberti, G. Schwarz (eds.), Italian Jews in Context, Palgrave (forthcoming 2018)

- 2018: „'The immortal traveler’. How historiography changed Judaism“, in: J. Rüpke (ed.), Creating Religions by Historiography, Archiv für Religionsgeschichte 20.1 (2018), 111-134.

- 2018/19: „The 'war zone' of the historical Jesus. Scholarship, politics, and religion in Italy 1890s1930s)", in: Ead., Lannoy A. (eds.) The other Jesus. Alternative histories of Jesus and the religious world of the past from the nineteenth and early twentieth centuries, Brepols: Turnhout.

- 2019: „Jewish Preaching, Space, and the Baroque“, in: A. Guetta, P. Savy (eds.), Non contrarii, ma diversi, Rome: Viella (delivered January 2018).

- 2019: „Religious polemics and 'regimes of historicity'. Interpreting the Magen ve-herev of Leon Modena", in: A. Destro, M. Pesce (eds.), Proceeding of the 2nd Annual Meeting on Christian Origins, Brepols: Turnhout (Delivered November 2017).

- 2019: „The Making of Wissenschaft des Judentums in a Catholic Country. The Case of Italy“, in: Christian Wiese, Mirjam Thulin (eds.), Wissenschaft des Judentums in Europe: Comparative and Transnational Perspectives, (Studia Judaica 76) de Gruyter, Berlin 2018 (delivered 2013, revised twice between 2014 and 2015).

- 2019: „Understanding 'prophecy': charisma, religious enthusiasm, and religious individualisation in the 17th century. A cross-cultural approach“", in Martin Fuchs et al. (eds.), Religious Individualisation: Historical Dimensions and Comparative Perspectives, Berlin: de Gruyter, 1299-1320.

- 2018: Books discussion: Aaron W. Hughes, Jacob Neusner. An American Jewish Iconoclast, New York: New York University Press, 2016, pp. 1-319; Amir Engel, Gershom Scholem. An Intellectual Biography, Chicago-London, The University of Chicago Press, 2017; George Prochnick, 
Stranger in a Strange Land: Searching for Gershom Scholem in Jerusalem, London: Granta, 2017 in Quest - Issues in Contemporary Jewish history 12/2 (2018)

\section{Feldhaus, Anne}

- 2018: „The Significance of Place in Early Mahānubhāv Literature“, in: B. Sengar and L. McMillin (eds.), Spaces and Places in Western India: Formations and Delineations, New Delhi: Routledge.

- 2019: „Individualisation, Deindividualisation, and Institutionalisation among the Early Mahānubhāvs", in: Martin Fuchs et al. (eds.), Religious Individualisation: Historical Dimensions and Comparative Perspectives, Berlin: de Gruyter, 831-846.

\section{Flügel, Peter}

-; Kornelius Krümpelmann (eds.) 2016. Johannes Klatt: Jaina-Onomasticon, Wiesbaden: Harrassowitz.

-; Sam Whimster (eds.) 2017. Special Issue (Part I): Max Weber's Hinduism and Buddhism: Reflections on a Sociological Classic 100 Years On, London: Max Weber Studies Office (Max Weber Studies 17, 2).

-; Sam Whimster (eds.) 2018. Special Issue (Part II): Max Weber's Hinduism and Buddhism: Reflections on a Sociological Classic 100 Years On, London: Max Weber Studies Office (Max Weber Studies 18, 1).

- 2019. Die Sthānakavāsī Śvetāmbara Jaina-Orden in Nordindien: Protestantische und Post-Protestantische Jaina-Reformbewegungen, Wiesbaden: Harrassowitz.

-; Sam Whimster (eds.) 2019. Max Weber's Hinduism and Buddhism: Reflections on a Sociological Classic 100 Years On. London, London: Max Weber Studies.

- 2016. „Life and Work of Johannes Klatt.“, in: Peter Flügel \& Kornelius Krümpelmann (eds.), Johannes Klatt: Jaina-Onomasticon Wiesbaden: Harrassowitz (Jaina Studies 1), 9-164.

- 2017: „Johannes Emil Otto Klatt (1852-1903). Forgotten Chronicler of Jainism and Bibliographer of Oriental Literature: Letters to Albrecht Weber 1874-1882, Ernst Kuhn 1881-1889, Charles Rockwell Lanman 1889 and Eberhardt Karras 1891, with Curriculum Vitae, and a Complete Bibliography of Johannes Klatt's Works.“, Berliner Indologische Studien 23, 69-141.

- 2018: „Social-Differentiation and Self-Differentiation: The Jaina Concept of the Individual and Sociological Individualisation-Paradigms“, Max Weber Studies 18, 2.

- 2018: „Reflexive Mechanisms and Agency in Jaina Law. The Maryādā Paț̣aka and Ācārya Sohanlāls Reforms of the Pañjāb Lavjī Ṛ̣i Sampradāya 1895-1911“, International Journal of Jaina Studies 14.

\section{Frenkel, Luise Marion}

- 2016: „Individual Christian voices in the narratives of late-antique acclamations“, RRE 2:2 (2016) 196-226, doi: http://dx.doi.org/10.1628/219944616X14655421286095.

- 2016: „The record of acclamations and cries in the Acts of Ephesus (431)“, in: Vinzent, M. \& Brent, A. (eds.) Studia Patristica. Vol. LXXIV - Including Papers presented at the Fifth British Patristics Conference, London, 3-5 September 2014. Leuven: Peeters, 303-316. 
- 2017: „The imperial identity of senatorial rituals in Late Antiquity.“, in: A. Zuiderhoek and W. Vanacker (eds.), Imperial identities in the Roman World, New York City: Routlegde, 199-218.

- 2018: „Procedural similarities between fourth and fifth-century Christian synods and the Roman Senates: myth, politics or cultural identity?“, in: Markus Vinzent (ed.), Studia Patristica. Vol. XCII - Papers presented at the Seventeenth International Conference on Patristic Studies held in Oxford 2015. Volume 18: Liturgica and Tractatus Symboli; Orientalia; Critica et Philologica; Historica. Studia Patristica 92. Leuven: Peeters, 293-302.

- 2018: „Mustering sources and vindication: Theodoret of Cyrrhus' sources and the models of Greek ecclesiastical historiography“, in: 0 . Devillers and B. B. Sebastiani (eds.), Les historiens grecs et romains: entre sources et modèles. Scripta Antiqua 109, Bordeaux: Ausonius Éditions, 349358.

- 2018: „Peace and Harmony at Church Councils and in the Roman Empire under Theodosius II.“, AHC 48 (1), Brill, 70-86.

- 2019: „Institutionalisation of the tradition and individualised lived Christian religion in Late Antiquity“, in: Martin Fuchs et al. (eds.), Religious Individualisation: Historical Dimensions and Comparative Perspectives, Berlin: de Gruyter, 1223-1254.

\section{Fuchs, Martin}

-; Antje Linkenbach, Wolfgang Reinhard, (eds.) 2015. Individualisierung durch christliche Mission?, Wiesbaden: Harrassowitz.

-; Vasudha Dalmia (eds.) 2019. Religious Interactions in Modern India, New Delhi: Oxford University Press.

- et al. (eds.) 2019. Religious Individualisation: Historical Dimensions and Comparative Perspectives. Berlin: de Gruyter.

- 2013: „Foreword“, in: Robinson, Rowena, Boundaries of Religion: Essays on Christianity, Ethnic Conflict, and Violence, New Delhi: Oxford Univ. Press, 11-15.

- 2013: „Vorwort“, in: Voigt, Viola, Interkulturelles Mentoring made in Germany: zum Cultural Diversity Management in multinationalen Unternehmen, Springer VS, 13-17.

- 2014: „Slum als Lebenswelt“, in: Karlheinz Sonntag (ed.), Arm und reich [Sammelband der Vorträge des Studium Generale der Ruprecht-Karls-Universität Heidelberg im Wintersemester 2012/2013], Heidelberg: Universitätsverlag Winter, 129-55.

- 2015: „Einleitung“, in: Individualisierung durch christliche Mission?, Wiesbaden: Harrassowitz, 13-37.

- 2015: „Introduction“, in: Individualisierung durch christliche Mission?, Wiesbaden: Harrassowitz, 38-63.

-; Jörg Rüpke 2015: „Religious individualization in historical perspective“, Religion 45.3 (2015), 323-329.

- 2015: „Processes of religious individualisation: Stocktaking and issues for the future“, Religion 45 (3), 330-43.

-; Jörg Rüpke 2015: „Religion: Versuch einer Begriffsbestimmung“, in: Bultmann, Christoph and Antje Linkenbach (eds.), Religionen übersetzen. Klischees und Vorurteile im Religionsdiskurs, Vorlesungen des Interdisziplinären Forums Religion der Universität Erfurt 11, Münster: Aschendorff, 17-21.

2016: „Alternative Genealogien von „Menschenwürde“ und „Menschenrechten“?: das universalistische Potential indischer Religionen und das Problem des übersetzerischen Anschlusses“, in: Esposito, Anna Aurelia; Oberlin, Heike; Viveka Rai, B.A. and Karin Juliana Steiner (eds.), In ihrer 
rechten Hand hielt sie ein silbernes Messer mit Glöckchen ...": Studien zur indischen Kultur und Literatur, Wiesbaden: Harrassowitz, 75-87.

- 2016: „Institutionalzing informal socialities: Dalit urban poor in Dharavi“, in: Hugo Gorringe et.al. (eds.), From the Margins to the Mainstream: Institutionalising Minorities in South Asia, London: Sage, 245-60.

- 2015: „Worldview and relations to the world: The concepts of karman and bhakti in Weber's study of Hinduism and Buddhism“, Sociological Problems 47 (3-4), 147-162 [in Bulgarian].

- 2016: „Worldview and relationships to the world: the concepts of karma(n) and bhakti in Weber's study on Hinduism and Buddhism“, Max Weber studies 16 (2), 211-27.

- 2017: „India in Comparison: Max Weber's Analytical Agenda“, in: Thomas C. Ertman (ed.), Max Weber's Economic Ethic of the World Religions: An Analysis, Cambridge: Cambridge University Press, 223-266.

- 2017: „Recognition across difference: conceptual considerations against an Indian background“, in: Dieter Gosewinkel, Dieter Rucht (eds.), Transnational struggles for Recognition. New perspectives on civil society since the twentieth century, New York/Oxford: Berghahn, 252-76.

- 2017: „Sociology of World Relations: Confronting the Complexities of Hindu Religions. A Perspective beyond Max Weber'“, Max Weber Studies 17 (2), 196-211.

- 2017: „,Hermeneutik des Neuen'. Ruptures and Innovations of Interpretation - Reflections from Indian Religious History: The Case of Bhakti, Social Imaginaries 3 (2), 57-75.

- 2017: „,Hermeneutik des Neuen'. Rotture e innovazioni nell'interpretazione religiosa. Rifessioni dalla storia religiosa indiana: il caso della bhakti“, in: Carlo Altini, Philippe Hoffmann and Jörg Rüpke (eds.), Issues of Interpretation. Texts, Images, Rites, Stuttgart: Franz Steiner, 225-242.

- 2018: „Indian Imbroglios: Bhakti Neglected, Or: the Missed Opportunities for a New Approach to a Comparative Analysis of Civilizational Diversity“, in: Arnason, Johann and Chris Hann (eds.), Anthropology and Civilizational Analysis. Eurasian Explorations, Albany (NY): SUNY Press, 121-154.

-; Antje Linkenbach, 2018: „Critique of Conversion - Conversion as Critique: M.K. Gandhi, B.R. Ambedkar and the Prerogative of Interpretation“, in: Rafael Klöber and Manju Ludwig (eds.), HerStory. Historical Scholarship between South Asia and Europe. Festschrift in Honour of Gita Dharampal-Frick, Heidelberg: CrossAsia-eBooks, 313-330.

- 2019: „Dhamma and the Common Good: Religion as Problem and Answer - Ambedkar's Critical Theory of Social Relationality“, in: Martin Fuchs and Vasudha Dalmia (eds.), Religious Interactions in Modern India, New Delhi: Oxford University Press, 364-413.

- 2019: „Transcending Selves, Introduction to Part I“, in: Martin Fuchs et al. (eds.), Religious Individualisation: Historical Dimensions and Comparative Perspectives, Berlin: de Gruyter, 35-49.

- 2019: „Self-affirmation, Self-transcendence and the Relationality of Selves: The Social Embedment of Individualisation in Bhakti“, in Martin Fuchs et al. (eds.), Religious Individualisation: Historical Dimensions and Comparative Perspectives, Berlin: de Gruyter, 257-288.

\section{Gordon, Richard L.}

- 2013: „Gods, guilt and suffering: Psychological aspects of cursing in the north-western provinces of the Roman Empire“, Acta Classica Universitatis Scientiarum Debreceniensis 49 (2013), 255-81.

- 2013: „Individuality, selfhood and power in the Second Century: The mystagogue as a mediator of religious options“, in: J. Rüpke and G. Woolf (eds.), Religious Dimensions of the Self in the Second century CE, STAC 76, Tübingen: Mohr-Siebeck, 146-172. 
- 2013: „The Religious anthropology of Late-antique ‘high’ Magical Practice“, in: J. Rüpke (ed.), Individualization in the Religions of the Ancient Mediterranean, Oxford: Oxford University Press 163-86.

- 2013: „,Will my child have a big nose?': Uncertainty, authority and narrative in katarchic astrology“, in: V. Rosenberger (ed.), Divination in the Ancient World: Religious Options and the Individual, Stuttgart: PawB 46, 93-137.

- 2015: „Religious competence and individuality: Three studies in the Roman Empire“, Religion 45.3 (2015), 367-385.

- 2015: „Showing the gods the way: Curse-tablets as deictic persuasion“, RRE 1.2 (2015), 148-180.

- 2016: „Den Jungstier auf der goldenen Schulter zu tragen. Mythos, Ritual und Jenseitsvorstellungen im Mithraskult“, in: K. Waldner, W. Spickermann, R.L. Gordon (eds.), Burial Rituals, Ideas of Afterlife, and the Individual in the Hellenistic World and the Roman Empire, Stuttgart: PawB 57, 219-253.

- 2016: „Negotiating the temple-script: Women's narratives among the 'confession-texts' of western Asia Minor“, in: RRE 2.2 (2016), 227-255.

- 2017: „Nature, order and well-being in the Roman cult of Mithras“, in: A. Hintze and A. Williams (eds.), Holy Wealth: Accounting for this World and the Next in Religious Belief and Practice: Festschrift for John R. Hinnells, Iranica 24, Wiesbaden: Harrassowitz, 93-130.

- 2017: „From East to West: Staging Religious Experience in the Mithraic Temple“, in: S. Nagel, J.-F. Quack and C. Witschel (eds.), Entangled Worlds: Religious Confluences between East and West in the Roman Empire. The Cults of Isis, Mithras and Jupiter Dolichenus. Proceedings of the Colloquium held at Heidelberg 26-29 Nov. 2009, Orientalische Religionen in der Antike 22, Tübingen: Mohr Siebeck, 413-442.

- 2017: „'Straightening the paths': Inductive Divination, Materiality and Imagination in the GraecoRoman Period“, in: Claudia Moser and Jennifer Knust (eds.), Ritual Matters: Material Remains and Ancient Religion, Memoirs of the American Academy in Rome, Supplementary vol. 13 Ann Arbor: University of Michigan Press, 119-143.

- 2019: „Subordinated religious specialism and individuation in the Graeco-Roman world“, in: Martin Fuchs et al. (eds.), Religious Individualisation: Historical Dimensions and Comparative Perspectives, Berlin: de Gruyter, 985-1008.

\section{Gräb-Schmidt, Elisabeth}

- 2013: „Säkularisierung und der Ruf nach Werten. Zur kategorialen Bedeutung der Freiheit im Zeitalter ihrer Gefährdungen“, in: N. Slenczka, (Hrsg.), Was sind legitime außenpolitische Interessen? Unverfügbare Voraussetzungen des säkularen Staates. Umgang mit Schuld in der Öffentlichkeit. (BThZ 2013), Leipzig: EVA Leipzig, 96-113.

- 2013: „Time and Eternity - The ontological impact of Kiergegaard's conception of time as a contribution to the question of the reality of time and human freedom “, in: A. Nicolaidis, W. Achtner (Hrsg.), The Evolution of Time. Studies of Time in Science, Anthropology, Theology, Oak Park, 162-184.

- 2014: „Wie kommt das Gute in die Welt? Natur und Freiheit des Menschen im Spannungsfeld von Soziobiologie, Ethik und Religion“, in: Th. Schlag, H. Simojoki (Hrsg.), Mensch - Religion - Bildung. Religionspädagogik in anthropologischen Spannungsfeldern. Gütersloh: Gütersloher Verlagshaus, 340-351.

- 2015: „Der Mensch - seine Natur als Freiheit. Zu den Bestimmungen des Verhältnisses von Natur und Freiheit in anthropologischer, kosmologischer und verantwortungsethischer Absicht", in: dies., R. Preul (Hrsg.), Natur (MJTh 27 / MThSt 122), Leipzig: EVA Leipzig, 29-50. 
- 2015: „Der lebendige Grund personaler Identität. Überlegungen zu einem leibbezogenen Personkonzept im Anschluss an Wilhelm Dilthey“, in: E. Gräb-Schmidt, M. Heesch, F. Lohmann, D. Schlenke, Ch. Seibert (Hrsg.), Leibhaftes Personsein. Theologische und interdisziplinäre Perspektiven. (MThSt 123), Leipzig: EVA, 77-96.

- 2016: „Religion und Freiheit. Zur emanzipativen Kraft der Transzendenz“, in ZThK 113 (2016) 2, 195-233.

- 2017: „Autonome Systeme. Autonomie im Spiegel menschlicher Freiheit und ihrer technischen Errungenschaften“, Zeitschrift für Evangelische Ethik (ZEE) 61, Gütersloh: Gütersloher Verlagshaus, 163-170.

- 2017: „Freiheit als Freiwerden. Phänomenologische Bestimmungen der neuzeitlichen Freiheit“, in: T. Söding, B. Oberdorfer (Hrsg.), Kontroverse Freiheit, Freiburg: Herder, 16-32.

- 2017: „Nachhaltigkeit im Zeichen reformatorischer Freiheit“, in: T. Jähnichen u.a. (Hrsg.), Rechtfertigung - Folgenlos? Jahrbuch Sozialer Protestantismus, Bd. 10, Leipzig: Evangelische Verlagsanstalt, 113-129.

- 2017: „Das Gleichgewicht zwischen dem Ästhetischen und dem Ethischen in der Herausarbeitung der Persönlichkeit: Das Versteckspiel des Lebens und der Ernst der Authentizität“, in: H. Deuser, M. Kleinert (Hrsg.), Søren Kierkegaard: Entweder - Oder (Klassiker Auslegen 67), Berlin/ New York: de Gruyter, 193-211.

- 2017: „Menschenrechte und Christentum. Metaphysische und rechtssystematische Überlegungen zur Frage ihrer Geltung und Universalisierung“, in: S. Altmeyer u.a. (Hrsg.), Menschenrechte und Religionsunterricht (IRP 33), Göttingen: Vandenhoeck \& Ruprecht, 26-37.

- 2017: „Gerechtigkeit und Freiheit in den Institutionen“, in: U.Heckel, J.Kampmann, V.Leppin, Ch.Schwöbel (Hrsg.), Luther heute: Ausstrahlungen der Wittenberger Reformation, Tübingen: Mohr Siebeck, 319-350.

- 2018: „Freiheit und Selbsterkenntnis. Zur Bedeutung der Buße in der Anthropologie Luthers“, in Theologische Literaturzeitung (ThLZ) 143 Nr.6, 571-588.

- 2018: „Der Wirklichkeits- und Normativitätsanspruch der Ethik. Überlegungen zu Grundlegungsfragen der Ethik in reformatorischer Sicht“, in: M. Roth, M. Held (Hrsg.), „Was ist theologische Ethik? Grundbestimmungen und Grundvorstellungen“, Berlin/Boston: de Gruyter, 41-62.

- 2019: „Transcendence and Freedom: On the Anthropological and Cultural Centrality of Religion“, in Martin Fuchs et al. (eds.), Religious Individualisation: Historical Dimensions and Comparative Perspectives, Berlin: de Gruyter, 141-158.

\section{Haakonssen, Knud}

- (co-ed.) 2013. „David Hume“, International Library of Essays in the History of Political Thought, Aldershot, Hamps.: Ashgate, 2013.

- (ed.) 2014. „Modern International Thought. A symposium occasioned by David Armitage's Foundations of Modern International Thought“, special issue of History of European Ideas, 40 (2014).

- (co-ed.) 2015. „Thomas Reid on Society and Politics“, edited with an introduction. Edinburgh: Edinburgh UP.

- (ed.) 2016. „Language in Intellectual History: The Work of Hans Aarsleff“, special issue of History of European Ideas, 42 (2016).

- (co-ed.) 2017. „Ludvig Holberg (1684-1754). Learning and Literature in the Nordic Enlightenment“, London: Routledge.

- 2013: „Five questions to Knud Haakonssen“, in: Intellectual History: 5 Questions, ed F. Stjernfelt, M. Haugaard Jeppesen and M. Thorup, Copenhagen: Automatic Press, 71-77. 
- 2013: „Natural rights or political prudence? Toleration in Francis Hutcheson“, in: Natural Law and Toleration in the Early Enlightenment, eds J. Parkin and T. Stanton, Oxford: Oxford UP (Proceedings of the British Academy), 183-200.

- 2016: Indledning [Introduction], Ludvig Holberg, Introduction til Naturens og Folkerettens Kundskab, in: Ludvig Holbergs Skrifter: http://holbergsskrifter.dk/holberg-public/ view?docld=NF/NF_innl.page\&doc.view=minimal (2016).

- 2016: (co-author), „Natural law: Law, rights and duties“, in: A Companion to Intellectual History, ed R. Whatmore, Chicester, W. Sussex: Wiley-Blackwell, 2016, 377-401.

- 2016: „The Lectures on Jurisprudence“, in: Adam Smith. His Life, Thought and Legacy, ed Ryan Hanley, Princeton: Princeton UP, 48-66.

- 2017: „Early-modern natural law theories“, in: Cambridge Companion to Natural Law Jurisprudence, ed George Duke and Robert P. George, Cambridge: Cambridge UP, 76-102.

- 2017: Introduction, part 2: The author and the work, in: Ludvig Holberg (1684-1754). Learning and Literature in the Nordic Enlightenment, ed K. Haakonssen \& S. Olden Jørgensen, London \& New York: Routledge, 2017, 13-26.

- 2017: „Holberg's Law of Nature and Nations“, in: Ludvig Holberg (1684-1754). Learning and Literature in the Nordic Enlightenment, ed K. Haakonssen \& S. Olden Jørgensen, London \& New York: Routledge, 59-79.

- 2017: „Pufendorf on power and liberty“, On-line discussion forum (January 2017): http://oll.libertyfund.org/pages/lm-pufendorf.

- 2018: „Natural law and moral philosophy“, in: Cambridge Companion to the Scottish Enlightenment, ed Alexander Broadie \& Craig Smith, Cambridge: Cambridge UP, forthcoming 2018.

- 2018: „Om Natur- og folkeretten“, in: Ludvig Holberg, Natur- og folkeretten (Ludvig Holbergs Hovedværker, vol. 19), Copenhagen \& Aarhus: Det Danske Sprog- og Litteraturselskab \& Aarhus Universitetsforlag, 11-35.

- 2016: Review article of Benjamin Straumann, Roman Law in the State of Nature, in: Bryn Mawr Classical Review, 2016: http://bmcr.brynmawr.edu/2016/2016-01-32.html

\section{Haas, Cornelia}

- 2013: „Jagadamba tanzt. Rukmini Devi und das World-Mother-Movement“, in: Stephan Koehn und Heike Moser (Hg.): Frauenkörper/Frauenbilder. Inszenierungen des Weiblichen in den Gesellschaften Süd- und Ostasiens. Wiesbaden: Harrassowitz, 161-177.

- 2014: „The Logoi and the Dragon in der „vergleichenden Mythologie“ Helena Blavatskys“, in: Cyril Brosch und Annick Payne (Hg.): Na-wa/i-VIR.ZI/A. MAGNUS.SCRIBA. Festschrift für Helmut Nowicki zum 70. Geburtstag. Herausgegeben von Cyril Brosch und Annick Payne. Wiesbaden: Harrassowitz (Dresdner Beiträge zur Hethitologie 45), 79-94.

- 2015: „From Theosophy to Indian Religions - The Conversions of Helena Blavatsky and Henry Steel Olcott to Buddhism“, in: Antje Linkenbach / Martin Fuchs / Wolfgang Reinhard (Hg.): Individualisierung durch christliche Mission? Wiesbaden: Harrassowitz, 505-515.

- 2015: „United Lodge of Theosophists India - Transcultural Re-Definition of Indian History of Ideas in the Urban Context of the High-Tech-Metropolises Mumbai and Bangalore“, in: Capitales de l'ésoterisme européen et dialogue des cultures. Paris: Orizons, 197-209.

- 2019: „Varieties of spiritual individualisation in the theosophical movement: the United Lodge of theosophists India as climax of individualisation-processes within the theosophical movement”, in: Martin Fuchs et al. (eds.), Religious Individualisation: Historical Dimensions and Comparative Perspectives, Berlin: de Gruyter, 1365-1380. 


\section{Henderson, Ian $\mathrm{H}$.}

- 2013: „Mark's Gospel and the Pre-History of Individuation“, in: (ed.) Jörg Rüpke, Religious individuation in the Ancient Mediterranean, Oxford: Oxford University Press, 269-297.

- 2015: „The Child, Death and the Human in Mark's Gospel“, in: (eds.) Ulrike Mittmann and Beate Ego, Evil and Death: Conceptions of the Human in Biblical, Early Jewish, Early Christian, GrecoRoman and Egyptian Literature (Deuterocanonical and Cognate Literature 18; Berlin: de Gruyter, 2015), 199-219.

- 2019. „,... quod nolo, illud facio’ (Romans 7:20): institutionalizing the unstable self“, in: Martin Fuchs et al. (eds.), Religious Individualisation: Historical Dimensions and Comparative Perspectives, Berlin: de Gruyter, 807-830.

\section{Herrmann-Pillath, Carsten}

- 2015. Culture: The Ritual Order of State and Markets, London: Routledge.

- 2017. Wachstum, Macht und Ordnung. Eine wirtschaftsphilosophische Auseinandersetzung mit China, Marburg: Metropolis.

- 2016: „Fei Xiaotong's comparative theory of Chinese culture: Its relevance for contemporary cross-disciplinary research on Chinese 'collectivism'“, Copenhagen Journal of Asian Studies 34(1), 25-57.

-; Man Guo 2016: „Ritual and property: Theorizing a Chinese case“, Man and the Economy 4(1), doi: 10.1515/me-2017-0004.

-; Björn Vollan, Zhou Yexin, Andreas Landmann \& Hu Biliang 2017: „Cooperation and Authoritarian Values: An Experimental Study in China“, European Economic Review 93, April 2017, 90-105.

- 2016: „Performativity, Performance and Politics: Towards an Evolutionary Taxonomy of Economic Systems“", Schmollers Jahrbuch 136(3), 257-284.

-; Feng, Xingyuan 2017: „Cultural Entrepreneurship in China (February 21, 2017) „, Available at SSRN: https://ssrn.com/abstract=3040490.

-; Guo, Man 2017: „Power, Property and Governmentality in South China: The Case of the Wen (Man) Clan in Hong Kong and Shenzhen (December 18, 2017) „, Available at SSRN: https://ssrn.com/abstract=3089728.

- 2018: 'Iclan’: „The Chinese Ritual Economy in the 21st Century (April 22, 2018)“, Available at SSRN: https://ssrn.com/abstract=3166765.

-; Man Guo 2019. „Lineage, Food and Ritual in a Chinese Metropolis“, Anthropos 114. 195-207.

- 2019: „Religious individualisation in China: a two-modal approach“, in: Martin Fuchs et al. (eds.), Religious Individualisation: Historical Dimensions and Comparative Perspectives, Berlin: de Gruyter, 643-668.

\section{Höke, Vera}

- 2019: Individualisation in conformity: Keshab Chandra Sen and canons of the self, in: Martin Fuchs et al. (eds.), Religious Individualisation: Historical Dimensions and Comparative Perspectives, Berlin: de Gruyter, 1381-1400. 


\section{Hoffmann, Veronika}

- (ed.) 2017. Nachdenken über den Zweifel. Theologische Perspektiven, Ostfildern.

- 2017: Einleitung, in: Ead. (Hg.): Nachdenken über den Zweifel. Theologische Perspektiven, Ostfildern, 7-20.

- 2017: „Zweifel, Säkularität und Identität“, in: Ead. (Hg.): Nachdenken über den Zweifel. Theologische Perspektiven, Ostfildern, 21-35.

- 2018: „,Zu gläubig“, um tolerant zu sein? Erkundungen im Spannungsfeld von Glaubensgewissheit, Zweifel und Toleranz", in: Kirschner, Martin; Ruhstorfer, Karlheinz (Hgg.): Die gegenwärtige Krise Europas. Theologische Antwortversuche, Freiburg (QD 291), 274-293.

- 2019: „Individualised versus institutional religion: Is there a mediating position?“ in: Martin Fuchs et al. (eds.), Religious Individualisation: Historical Dimensions and Comparative Perspectives, Berlin: de Gruyter, 1121-1138.

\section{Hu-von Hinüber, Haiyan}

- 2018: „What to do if the Owner of a Monastry is put in jail? The Samgha’s Begging Area according to Early Vinaya Texts“, in: Saddharmāmrtam. Festschrift für Jens-Uwe Hartmann zum 65. Geburtstag, herausgegeben von O. von Criegern, G. Melzer und J. Schneider, Wien 2018 (Wiener Studien zur Tibetologie und Buddhismuskunde, Heft 93), 201-213.

\section{Kleinert, Matthias}

-; Gerald Hartung (eds.) 2017. Humor und Religiosität in der Moderne, Wiesbaden: Springer.

\section{Klostergaard Petersen, Anders}

2019: Suifaction: typological reflections on the evolution of the self, in: Martin Fuchs et al. (eds.), Religious Individualisation: Historical Dimensions and Comparative Perspectives, Berlin: de Gruyter, 185-214.

\section{Kouroshi, Yahya}

- 2016: „Medialität und Modalität der Prophetie. Die Rezeption der Geschichte Christi am Hof der Großmogulherrscher in Indien um 1600 anhand von Schriften des Jesuiten Jeronimo Xavier“, in: Jamal Malik et al. (Hgg.), Religionen in Bewegung. Interreligiöse Beziehungen im Wandel der Zeit, Münster: Aschendorff, 123-141.

- 2018: „Poetik und Grammatik des Blicks: Goethes Symbol-Begriff vom Euphrat aus betrachtet“, in: Christine Maillard/Hamid Tafazoli (Hgg.), Persien im Spiegel Deutschlands. Konstruktionsvarianten der Persienbilder in der deutschsprachigen Literatur vom 18. bis in das 20. Jahrhundert, Strasbourg: Presses universitaires de Strasbourg, 243-263. 


\section{Liedhegener, Antonius}

- 2012: „,Neue Religionspolitik’ in der verfassungsstaatlichen Demokratie? Religionsfreiheit als Schranke und Ziel politischen Entscheidens in religiös-kulturellen Konflikten“, in: Bogner, Daniel/Heimbach-Steins, Marianne (Hg.), Freiheit - Gleichheit - Religion. Orientierungen moderner Religionspolitik (= Religion und Politik, Bd. 4) Würzburg, 111-130.

- 2014: „Religion, Bürgergesellschaft und Pluralismus. Gesellschaftliche und politische Integration aus der Perspektive demokratischer politischer Systeme“, in: Arens, Edmund (Hgg.), Integration durch Religion? Geschichtliche Befunde, gesellschaftliche Analysen, rechtliche Perspektiven (= Religion - Wirtschaft - Politik, Bd. 10) Baden-Baden - Zürich, 63-84.

- 2014: „Säkularisierung als Entkirchlichung. Trends und Konjunkturen in Deutschland von der Mitte des 19. Jahrhunderts bis zur Gegenwart“, in: Gabriel, Karl/Gärtner, Christel/Pollack, Detlef (Hg.), Umstrittene Säkularisierung. Soziologische und historische Analysen zur Differenzierung von Religion und Politik, 2. durchges. und um ein Reg. erg. Aufl., Berlin, 481-531.

- 2015: „Nachkriegszeit (1945-1960)“, in: Hölscher, Lucian/Krech, Volkhard (Hg.), Handbuch der Religionsgeschichte im deutschsprachigen Raum, Bd. 6,1:20. Jahrhundert - Epochen und Themen, Paderborn, 135-174, 449-455 und 554-559.

- 2016: „Ein kleiner, aber feiner Unterschied. Religion, zivilgesellschaftliches Engagement und soziale Integration in der Schweiz“, in: Arens, Edmund (Hgg.), Integrationspotenziale von Religion und Zivilgesellschaft. Theoretische und empirische Befunde (= Religion - Wirtschaft Politik, Bd. 14) Baden-Baden - Zürich, 121-181.

- 2016: „Religiöse Identitäten als Problem wechselseitiger Identifizierungen und Kategorisierungen. Aktuelle theoretische Konzepte und Fragen ihrer Operationalisierung in der empirischen Religionsforschung“, in: Werkner, Ines-Jacqueline/Hidalgo, Oliver (Hg.), Religiöse Identitäten in politischen Konflikten (= Politik und Religion), Wiesbaden, 65-82.

- 2018: „Pluralisierung“, in: Krech, Volkhard/Pollack, Detlef/Hero, Markus/Müller, Olaf (Hg.), Handbuch Religionssoziologie, Wiesbaden, 347-382.

\section{Linkenbach, Antje}

-; Martin Fuchs; Wolfgang Reinhard (eds.) 2015, Individualisierung durch Christliche Mission?, Wiesbaden: Harrassowitz, (Studien zur Außereuropäischen Christentumsgeschichte - Asien, Afrika, Lateinamerika).

-; Christoph Bultmann (eds.) 2015, Religionen Übersetzen: Klischees und Vorurteile im Religionsdiskurs, Münster: Aschendorff.

- et al. (eds.) 2019. Religious Individualisation: Historical Dimensions and Comparative Perspectives. Berlin: de Gruyter.

- 2014: „Religion, Säkularisierung und Rechtspluralismus im modernen Indien“, in: Benedikt Kranemann, Christof Mandry, Hans-Friedrich Müller (Hrsg), Religion und Recht, Münster: Aschendorff, 137-162.

- 2015: „The World Religion of Hinduism: On the Construction of the Image of India in German Textbooks", in Eckert.bulletin 15, 14-17.

- 2015: „Weltreligion Hinduismus: Zur Konstruktion des Indienbildes in deutschen Schulbüchern“, in: Christoph Bultmann, Antje Linkenbach (Hrsg.), 2015, Religionen Übersetzen: Klischees und Vorurteile im Religionsdiskurs, Münster: Aschendorff, 23-44. 
- 2016: „Bewegungen für Umweltgerechtigkeit in Indien“, in: Handbuch Entwicklungsforschung, hrsg. von Manuela Boatca, Karin Fischer und Gerhard Hauck; Springer NachschlageWissen (online) 2015. Druckversion 2016.

- 2016: „Interreligiosität in Indien in historischer Perspektive“, in: Michael Gabel, Jamal Malik, Justyna Okolowicz (Hrsg.), Religionen in Bewegung: Interreligiöse Beziehungen im Wandel der Zeit, Münster: Aschendorff, 99-122.

- 2016: „Soziale Bewegungen und selbstbestimmte Entwicklung“, in: Handbuch Entwicklungsforschung, hrsg. von Manuela Boatca, Karin Fischer und Gerhard Hauck; Springer NachschlageWissen (online), 2015. Druckversion 2016.

- 2017: „Environmental Justice in India? Examining the Compatibility between Sustainability, Social Justice and the Gandhian legacy“, in Journal of Social and Economic Studies (ANSISS), 2017, 27.1.

- 2017: „Gender Dynamics and Equality in India: A Plea for an Integrative Approach to Social Justice“, in RDWU Journal of Social Sciences and Humanities, 2017, Vol. 2, 5-21.

- 2017: „Sustainable Development in a Dharmic Land? Environmental and Political Protest in Uttarakhand“, in: Joshi, B.K. and Joshi, Maheshwar P. (eds.), Unfolding Central Himalaya: The Cradle of Culture, Dehra Dun: Doon Library and Research Center; Almora: Almora Book Depot, 296-324.

-; Martin Fuchs, 2018: „Critique of Conversion - Conversion as Critique: M.K. Gandhi, B.R. Ambedkar and the Prerogative of Interpretation“, in: Rafael Klöber and Manju Ludwig (eds.), HerStory. Historical Scholarship between South Asia and Europe. Festschrift in Honour of Gita Dharampal-Frick, Heidelberg: CrossAsia-eBooks, 313-330.

- 2018: „Travelling Deities: Ritual, Territory and Authority in the Central Himalayas (India). The Hermeneutics of Ethnographic Research“, in: Carlo Altini, Philippe Hoffmann, Jorg Rüpke (eds.), Issues of Interpretation. Texts, Images, Rites, Stuttgart: Franz Steiner, 253-268.

-2018: „Projecting a New Anthropology? Some reflections on Lawrence Krader's contribution to the discipline of anthropology and his significance today", in: Cyril Levitt and Sabine Sander (eds.), Beyond the Juxtaposition of Nature and Culture. Lawrence Krader, Interdisciplinarity, and the Human Being, New York: Peter Lang (New York), 133-149.

-2019: „Der Tod der Muttersprache“ -Sprache und Sprachpolitik in Indien, in: Südasien 39.2, 7-12.

-2019: „The Empathic Subject and the Question of Dividuality“, in: Martin Fuchs et al. (eds.), Religious Individualisation: Historical Dimensions and Comparative Perspectives, Berlin: de Gruyter, 383-408.

-; Martin Mulsow, 2019: „The Dividual Self: Introduction to Part 2“, in: Martin Fuchs et al. (eds.), Religious Individualisation: Historical Dimensions and Comparative Perspectives, Berlin: de Gruyter, 323-344.

\section{Maier, Harry 0.}

- 2019: Paul's Letter to Philemon: a case study in individualisation, dividuation, and partibility in Imperial spatial contexts, in: Martin Fuchs et al. (eds.), Religious Individualisation: Historical Dimensions and Comparative Perspectives, Berlin: de Gruyter, 519-540.

\section{Malik, Aditya}

-; Sweetman, Will (eds.) 2016. Hinduism in India: Modern and Contemporary Movements. New Delhi: Sage Publications. 
- 2016. Tales of Justice and Rituals of Divine Embodiment: Oral Narratives from the Central Himalayas. New York: Oxford University Press (pb 2018).

- 2015: „The darbar of Goludev: Possession, Petitions, and Modernity“, in: William S. Sax and Helene Basu (eds.) The Law of Possession. Ritual, Healing, and the Secular State (193-225). New York: Oxford University Press.

- 2016: „Folk Hinduism: The Middle Ground?“, in: Will Sweetman and Aditya Malik (eds.) Hinduism in India: Modern and Contemporary Movements (176-193). New Delhi: Sage Publications.

- 2016: „Possession, Alterity, Modernity“, Introductory chapter in: Sekhar Bandyopadhyay and Aloka Parashar Sen (eds.) Religion and Modernity in India. (36-63). New Delhi: Oxford University Press.

- 2019. „The swirl of worlds: possession, porosity and embodiment“, in Martin Fuchs et al. (eds.), Religious Individualisation: Historical Dimensions and Comparative Perspectives, Berlin: de Gruyter, 559-582.

\section{Malinar, Angelika}

-; S. Müller (eds.) 2018. Asia and Europe - Interconnected: Agents, Concepts, and Things, Wiesbaden: Harrassowitz.

- 2013: „Mohandas Karamchand Gandhi“, in: K. A. Jacobsen, H. Basu, A. Malinar \& V. Narayanan (eds.) Brill's Encyclopedia of Hinduism. Vol. V, Leiden, Brill, 542-551.

- 2013: „,... western-born but in spirit eastern ...' - Annie Besant between Colonial and Spiritual Realms“, in: Asiatische Studien/Études Asiatiques 67, 4: 1115-1155.

- 2014: „,Following one's Desire' (kāmacāra): On a Characterisation of Freedom in Vedic literature and the Mahābhārata“, in: Asiatische Studien/Études Asiatiques 68, 4, 757-782.

- 2014: „Sensory Perception and Notions of the Senses in Sāṃkhya Philosophy“, in: A. Michaels, Ch. Wulf (eds.), Exploring the Senses, Asian and European Perspectives on Ritual and Performativity, London: Routledge, 34-51.

- 2015: „Religion“, in: G. Dharampal-Frick et al. (eds.). Key Concepts in Modern Indian Studies, New York, Oxford: Oxford University Press, 289-297.

- 2015: „Religionsfreiheit und Hinduismus“, in: H. Ziebertz (ed.). Religionsfreiheit: Positionen, Konflikte, Herausforderungen, Würzburg: Echter, 183-210.

- 2015: „Religious Pluralism and Processes of Individualization in Hinduism“, in: Religion 45, 3 , 386-408.

- 2016: „Konfigurationen von Mystik zwischen Indien und Europa“, in: Meister Eckhart Jahrbuch 10, 103-120.

- 2017: „Narrating Sāṃkhya Philosophy: Bhīṣma, Janaka and Pañcaśikha at Mahābhārata 12.21112“, in: Journal of Indian Philosophy 45, 4, 609-649.

- 2017: „Philosophy in the Mahäbhärata and the History of Indian Philosophy“, in: Journal of Indian Philosophy 45, 4, 587-604.

- 2017: „Religious Pathways: Social and Ritual Activity (karman), Knowledge (jñāna), Devotion (bhakti)", in: G. Oddie and G. Bailey (eds.), Handbook of Hinduism, New Delhi: Sage.

- 2018: „Karmic Histories and the Synthesis of 'East and West'. Annie Besant on Hinduism“, in:

A. Malinar \& S. Müller (eds.), Asia and Europe - Interconnected: Agents, Concepts, and Things, Wiesbaden: Harrassowitz.

- 2019: „Religious plurality and individual authority in the Mahahbharata“, in: Martin Fuchs et al. (eds.), Religious Individualisation: Historical Dimensions and Comparative Perspectives, Berlin: de Gruyter. 1173-1200. 


\section{Mersch, Katharina}

- 2013: „Göttlich legitimierter Eigensinn. Gewissensfreiheit als Option im Umgang mit dem exkommunizierten Ludwig dem Bayern und dem Interdikt“, in Frühmittelalterliche Studien 47 (2013), 209-238.

- 2018: „Überlegungen zum Verhältnis von Schuld, Reue und Intention am Beispiel der Ermordung des Erzbischofs Burchard III. von Magdeburg“, in: hrsg. von Jan-Hendryk de Boer und Marcel Bubert (Kontingenzgeschichten), Absichten, Pläne, Strategien. Erkundungen eines Problems der Vormoderneforschung, 141-174.

- 2019: „Out of bounds, still in control. Exclusion, religious individuation and individualisation during the later Middle Ages“, in: Martin Fuchs et al. (eds.), Religious Individualisation: Historical Dimensions and Comparative Perspectives, Berlin: de Gruyter. 1321-1350.

- 2014: Rezension: Jaser, Christian, „Ecclesia maledicens. Rituelle und zeremonielle Exkommunikationsformen im Mittelalter“, Tübingen: Mohr Siebeck 2013, in sehepunkte 14 (2014), Nr. 4 [15.04.2014]. http://www.sehepunkte.de/2014/04/24545.html.

- 2014: Rezension: „,hrsg. von Letha Böhringer, Jennifer Kolpacoff Deane, Hildo van Engen, „Labels and Libels. Naming Beguines in Northern Medieval Europe (Sanctimoniales 1)", Turnhout 2014, in Archa Verbi 11 (2014), 210-212.

- 2017: Rezension: Franz-Josef Arlinghaus (ed.), „Forms of Individuality and Literacy in the Medieval and Early Modern Periods“, Turnhout: Brepols Publishers, 2015, in Historische Zeitschrift 304/2 (2017), 432f.

\section{Mieth, Dietmar}

- 2013. Ein Weg der Erfahrung mit Meister Eckhart durch Erfurt. Erfurt (engl. Übers.: Markus Vinzent).

-; Dagmar Gottschall in Zusammenarbeit mit Katharina Mersch (eds.) 2013, Meister Eckharts „Reden an die Stadt“ (Meister Eckhart Jahrbuch, Bd.6), Stuttgart: Kohlhammer.

- 2013. Meister Eckharts Faszination heute. Erfurt (englische Übers.: Markus Vinzent).

- 2014. Meister Eckhart. München: Beck.

- 2018. Im Wirken schauen. Die Einheit von vita activa und vita contemplativa bei Meister Eckhart und Johannes Tauler. Neu mit Text, Übersetzung und Kommentar zur Predigt Meister Eckharts über Maria und Martha (2003). Darmstadt: Wiss. Buchgesellschaft. Neudruck (first ed. 1969).

-; Irene Mieth 2019. Sterben und Lieben. Selbstbestimmung bis zuletzt. Freiburg i.Br.: Herder.

-; Britta Müller-Schauenburg (eds.) 2012, Mystik, Recht und Freiheit. Religiöse Erfahrung und kirchliche Instituionen im Spätmittelalter. Stuttgart: Kohlhammer.

- (ed.) 2014. Meister Eckhart, Einheit mit Gott. Die bedeutendsten Schriften zur Mystik. 2. Aufl. der Neuausgabe. Ostfildern: Patmos.

- (ed.) 2014, Meister Eckhart. Vom Atmen der Seele. Stuttgart: Reclam.

-; Marcus Düwell, Jens Braarwig, Peter Brownsword (eds.) 2014. The Cambridge Handbook of Human Dignity, Interdisciplinary Perspestives. Cambridge: University Press.

-; Monika Bobbert (eds.) 2015. Das Proprium der christlichen Ethik. Luzern: Exodus

-; Christine Büchner, Markus Enders (eds.) 2016. Meister Eckhart interreligiös = Jahrbuch der Meister Eckhart Gesellschaft, Bd. 10. Stuttgart: Kohlhammer.

-; Marie-Anne Vannier, Markus Vinzent Christoph Wojtulewicz (eds.) 2016. Meister Eckhart in Paris and Strasbourg (Eckhart Texts and Studies, vol. 5). Louvain: Peeters. 
- (ed.) 2017. Anfänge der religiösen Selbstbestimmung im Mittelalter = special issue Theologische Quartalschrift 197, 1. Ostfildern: Schwabenverlag.

-; Freimut Löser (eds.) 2019. Unterscheiden lernen. Meister Eckharts Erfurter Lehrgespräche, Text, Übersetzung, Kommentar. Ostfildern: Grünewald.

-; Regina Schiewer (eds.) 2019. Religiöse Selbstbestimmung, Anfänge im Spätmittelalter, Beiheft 7 zum Meister-Eckhart-Jahrbuch Gesellschaft, Stuttgart: Kohlhammer.

- 2013: „Die individuelle Unmittelbarkeit der Mystik als Herausforderung der Religionen“, in: Evangelischer Pressedienst (EPD) Dokumentation Nr. 34 „Nachdenken über Meister Eckhart“, vom 20.8. 2013, Frankfurt a.M., 30-38.

- 2013: „Die Meister sagen - die Leute fragen. Denken, rhetorische Intensität und Didaktik in den Reden der Unterweisung Meister Eckharts“, in: Dagmar Gottschall, Dietmar Mieth (Hrsg.), Meister Eckhart Jahrbuch 7, Meister Eckharts Reden an die Stadt, Stuttgart: Kohlhammer, 325-346.

- 2013: „Meister Eckhart als interreligiöse Integrationsfigur“, Zuerst in: hg.v. Katja Becker, FrankThilo Becher, Wolfgang Achtner, Magister, Mystiker, Manager. Meister Eckharts integrale Spiritualität, Giessen 2012, 74-85, ferner in: Rainer Funk zum 70. Geburtstag, hg. v. Helmut Johach und Burkhard Bierhoff, Humanismus in der Postmoderne, Pfungstadt, 129-141.

- 2013: „Meister Eckhart’s God“, in: Jeanine Diller, Asa Kasher (eds.), Models of God and Alternative Realities, Dordrecht: Springer, 801-810.

- 2013: „Menschenwürde - vormoderne Perspektiven am Beispiel zweier Impulse des Spätmittelalters“, in: Klaus Ridder, Steffen Patzold (Hg.), Die Aktualität der Vormoderne. Epochen-

Entwürfe zwischen Alterität und Kontinuität. Berlin: Akademie-Verlag, 319-340.

- 2013: „Reichtum und Armut bei Meister Eckhart“, in Theologische Quartalsschrift 193 (2013), 209-219.

- 2013: „Wert und Zeit. Über den richtigen Umgang mit der Zeit“, in Jahrbuch für Biblische Theologie 28 (2013), 271-294.

- 2014: „Das Freiheitsmotiv bei Meister Eckhart“, in: Freimut Löser/Dietmar Mieth, Hg., Der Meister im Original, Jahrbuch der MEG 7, Stuttgart: Kohlhammer, 79-104.

- 2014: „Der Umgang mit sich Selbst. Anselm Grüns Anleitungen zum guten Leben“, in: Thomas Philipp, Jörg Schwaratzki, Francois Xaver Amherdt (Hg.), Theologie und Sprache bei Anselm, Grün. Freiburg-Basel-Wien: Herder, 140-155.

- 2014: „Gelassenheit“, in: Erbe und Auftrag, Monastische Welt 90 (2014), 246-255.

- 2014: „Human Dignity in Late Medieval Spiritual and Political Conflicts“, in: Düwell, Brownsword, Braavig, Mieth, (eds.), The Cambridge Handbook on Human Dignity, Cambridge: University press 74-85.

- 2014: „Meister Eckhart interreligiös“, (Zusammenfassung) in: Zur Debatte, München 7/2014, 9-12.

- 2014: „Weisheit“, in: Anselm Grün begegnen. Münsterschwarzach: Vier Türme, 243-249.

- 2015: „Maria und Marta“, in: Rudolf Walter (Hg.), Inspiration für das Leben. Im Dialog mit der Bibel, Freiburg-Basel-Wien: Herder, 126-135.

- 2015: „The Outer and Inner Constitution of Human Dignity in Meister Eckhart“, in: Ulrich Schmiedel, James Matarazzo Jr. (eds.), Dynamics of Difference. Christianity and Alterity, a Festschrift for Werner G. Jeanrond, London: Bloomsbury, 71-78.

- 2016: „Der barmherzige Samariter und die narrative Ethik Jesu (Lk 10,25-37). Ein Essay über die Grundidee der Nächstenliebe, ihr Missverständnisse und ihre politische Bedeutung“, in: Paul Chummar Chittilappilly (Hg.), Horizonte gegenwärtiger Ethik, Freiburg i.Br.: Herder, 229-238. 
- 2016: „Der Himmel in mir. Die Interiorisierung des Himmels bei Meister Eckhart. ,Was oben war, ist innen ““, in: Harald Lesch, Bernd Oberndorfer (Hg.), Der Himmel als transkultureller ethischer Raum, Göttingen: Vandenhoek, 105-126.

-; Julie Casteigt, Jörg Rüpke 2016: „Der Träger der Erfurter Riesenthorahrolle. Eine religionsgeschichtliche Hypothese zu einem übersehenen Judaicum“, in Zeitschrift für Religions- und Geistesgeschichte 68,2, 98-118.

- 2016: „Die individuelle Unmittelbarkeit der Mystik als Herausforderung der Religionen? - Religiöse und nachreligiöse Perspektiven der Unmittelbarkeit, ausgehend von Meister Eckhart“, in: Büchner, Enders Mieth (Hg.) Meister Eckhart - interreligiös, Meister-Eckhart-Jahrbuch, Bd. 10, Stuttgart: Kohlhammer, 9-24.

- 2016: „Die Tugend der Gelassenheit“, in: Sei gelassen, Gedanken, Anregungen, Ruheplätze, Stuttgart: Reclam, 28-31.

- 2016: „Dynamics of Meister Eckhart - Past and Present“, in: Jutta Vinzent and Christopher Wojtulewiccz (eds.), Performing Bodies. Time and Space in Meister Eckhart and Taery Kim. Eckhart Texts and Studies, vol 6, Leuven: Peeters, 77-96.

- 2016: Einleitung „Meister Eckhart interreligiös“, in: Büchner, Enders Mieth (Hg.) Meister Eckhart interreligiös, IX-XXIII.

- 2016: „Meister Eckhart und Luther: ein Annäherungs- und Differenzierungsversuch“, in: Mariano Delgado, Volker Leppin (Hg.), Luther: Zankapfel zwischen den Konfessionen und „Vater im Glauben“, Historische, systematische und ökumenische Zugänge, Fribourg/Schweiz-Stuttgart: Kohlhammer, 52-74.

- 2016: „Perfektionierung und Meliorisierung (enhancement) - ein Versuch über Menschenbilder“, in: hg.v. Paul Lissmann, Neue Menschen, bilden, optimieren, perfektionieren, Wien, 220-252.

- 2017: „Demut bei Meister Eckhart“, in Wort und Antwort 58 (2017) Heft 3, 197-111.

- 2017: „Deutsche und Lateinische Werke Meister Eckharts. Ein kurzer Überblick“, Theologische Quartalschrift 197, Heft 1, 96-100.

- 2017: „Experiential Ethics and Religious Experience with Reference to Meister Eckhart“ in: Patrick Cooper - Satoshi Kikuchi (eds.), Commitments to Medieval Mysticism within Contemporary Contexts, Leuven-Paris-Bristol: Peeters, 195-222.

- 2017: „Geflügelte Motive und Leitbilder. Meister Eckhart liest Marguerite Porete“, in: Mieth, Vannier, Vinzent, Meister Eckhart Erfurt Paris Straßburg, Meister Eckhart, Texts and Studies, vol. 5, Leuven: Peeters, 1-19.

- 2017: „Gewissen“, in: Christine Büchner, Gerrit Spallek (Hg.), Auf den Punkt gebracht, Grundbegriffe der Theologie, Ostfildern: Grünewald, 77-90.

- 2017: „Innerlichkeit ohne Weltgestaltung? Der Weg von der ,devotio moderna“ zu den ,Stillen im Lande““ (Pietismus), in: Marie-Anne Vannier (Hg.), Mystique rhénane et Devotio Moderna, Paris, 267-282.

- 2017: „Leben und Leben oder: Lebensführung und Lebensforschung. Folgerungen für eine ,neue‘ Metaphysik im Sinne Hermann Deusers. Ein Essay“, in: hg. v. Matthias Kleinert und Heiko Schulz, Natur, Religion, Wissenschaft, Beiträge zur Religionsphilosophie Hermann Deusers, Tübingen, Mohr Siebeck, 421-438.

- 2017: „Meister Eckhart, Predigt 67: Deus Caritas est“, in Lectura Eckhardi IV, hg.v. Georg Steer und Loris Sturlese, Stuttgart: Kohlhammer, 95-122.

- 2017: „Über Mystik reden. Joseph Bernhart und Meister Eckhart“, in: Rainer Bendel, Josef Nolte (Hg.), Befreite Erinnerung, Teilband 2: Region-Religion-Identität: Tübinger Wege. Beiträge zu Theologie, Kirche und Gesellschaft Bd. 26, Berlin: Lit, 35-50.

- 2017: „Zu den Diskursen über Individualisierung, bezogen auf das Spätmittelalter“, Theologische Quartalschrift 197, Heft 1, 4-34. 
- 2018: „Contemplativus post actionem”, „contemplativus in actione” ou „contemplativus sine actione"? In: Marie-Anne Vannier (éd.), Les chemin spirituels dans la mystique thénane et la Devotio Moderna, Paris 2018, 53-78.

- 2018: „Perfektionierung und Meliorisierung („Enhancement“) - ein Versuch über Menschenbilder. Religiöse und ethische Perspektiven“. In: Die Perfektionierung des Menschen, hg. v. Thomas Bahne und Katharina Waldner (Vorlesungen des Interdisziplinären Forums Religion der Universität Erfurt, Bd. 13) Münster: Aschendorff, 19-42.

- 2018: „Migranten und Flüchtlinge. Solidarität als Anspruch an die Verteilung von Rechten und Pflichten“. In: Marie Jo Thiel, Marc Feix (Hg.), The Challenge of Fraternity - Die Herausforderung der Geschwisterlichkeit, Berlin: Lit 2018, 113-125.

- 2018: „Meister Eckhart, Opus tripartitum“. In: Religionsphilosophie und Religionskritik, Ein Handbuch, hg. v. Michael Kühnlein, Berlin: Suhrkamp, 126-137.

- 2018: „Christliche Sozialethik - Orientierung zu welcher Praxis?“ In: Bernhard Emunds (Hg.), Christliche Sozialethik - Orientierung zu welcher Praxis? Festschrift für Friedhelm Hengsbach, Baden-Baden: Nomos 2018, 201-218.

- 2018: „1968 - ein theologisches Jahr an der Universität Tübingen. Hans Küng zum 90. Geburtstag“. In: Revolte in der Kirche? Das Jahr 1968 und seine Folgen. Hg. im Auftrag des Theologischen Forschungskollegs der Universität Erfurt von Sebastian Holzbrecher, Benedikt Kranemann, Julia Knop und Jörg Seiler. Freiburg-Basel-Wien: Herder, 167-184.

- 2018: „,Exodus“ - Ein Exempel für ein mediales Missverständnis und ein religionskritischer Ertrag“. In: Ethik in Serie, hg. v. Cordula Brand und Simon Meisch, Festschrift zu Ehren von Uta Müller (Materialien zur Ethik in den Wissenschaften, Bd. 13). Tübingen 2018, 61-76.

- 2018: „Für Viele und für alle. Gegen die Opfertheorie im Christentum“. In: Hans-Gerd Janßen, Julia D.E. Prinz, Michael J. Rainer (Hgg.), Theologie in gefährdeter Zeit, Stichworte von nahen und fernen Weggefährten für Johannes Baptist Metz zum 90. Geburtstag, Berlin: Lit, 325-327.

- 2018: „Autonomie und Selbstbestimmung an den Polen des Lebens“. In: Wolfgang Beer u.a. (Hgg.), Weichenstellungen an den Polen des Lebens. Frankfurt a.M.: Wochenschau-Verlag, 77-96.

- 2018: „Die individuelle Unmittelbarkeit der Mystik als Herausforderung der Religionen?“, in: Erdal Toprakyaran, Hansjörg Schmid, Christian Ströbele (Hg.), Dem Einen entgegen, Christliche und islamische Mystik in historischer Perspektive (Transliminale Diskurse der Islamischen Theologie, Bd. 2), Berlin: Lit, 9-26.

- 2019: „Der Aufstieg des, gewerbes‘: Meister Eckhart, Martin Luther und Max Weber. Historischsystematische Betrachtungen“. In: Volker Leppin, Freimut Löser (Hg.) Meister Eckhart und Martin Luther, Jahrbuch der Meister Eckhart Gesellschaft, Bd. 13. Stuttgart: Kohlhammer 2019, 139-168.

- 2019: „Die Entstehung des Bildungsgedankens bei Meister Eckhart“. Theologische Quartalschrift 199 (2019) Heft 2, 75-96.

- 2019: „Dynamische Stabilisierung und resonante Weltbeziehung. Laudatio für den soziologischen Diagnostiker Hartmut Rosa“. In: Gefangen in der Gesellschaft, FrommForum 23, Tübingen 2019, 133-143. Auch in: Resonanz, Im interdisziplinären Gespräch mit Harmut Rosa, hg. v. Jean Pierre Wils, Frankfurt a.M. 2019, 179-190.

- 2019: „,Herz“ bei Meister Eckhart“. In: Jens Haustein, Regina D. Schiewer, Martin Schubert, Rudolf Kilian Weigand (Hgg.), Traditionelles und Innovatives in der geistlichen Literatur des Mittelalters, Freimut Löser zum 65. Geburtstag, Meister-Eckhart-Jahrbuch, Beiheft 5 , hg. v. Regina Schiewer, Stuttgart: Kohlhammer, 1-24.

- 2019: „Narrative Ethik als Moralische Verunsicherung durch Literatur“. In: Volker Sühs (Hg.), Die entscheidenden Fragen der Zukunft, Theologen und Theologinnen nehmen Stellung, Essays anlässlich 100 Jahren Matthias Grünewald Verlag, Ostfildern: Grünewald, 117-123. 
- 2019: „Meister Eckhart: Kontemplation und Gottesgeburt. Die religiöse Erfahrung des Christentums und die christliche Erfahrung des Religiösen“. In: Marie-Anne Vannier (Hg.), Meister Eckhart und die Kirchenväter, Paris: Beauchesne 18-44.

- 2019: „,Gefährliche Religion(en)‘. Die Ambivalenz religiöser Narrative und die weitere Entwicklung eines ,Weltethos““. In: Daniel Bogner (Hg.), Moraltheologie im Disput, Fribourg: Echter.

- 2019: „Religiöse Individualisierung und Selbstbestimmung. Soziale Plurivalenzen und Widersprüche der Selbstbestimmung, damals und heute“. In: Dietmar Mieth, Regina Schiewer (eds.), Religiöse Selbstbestimmung, Anfänge im Spätmittelalter, Beiheft 7 zum Meister-EckhartJahrbuch, Stuttgart: Kohlhammer.

- 2019: „Marguerite Poretes Lebenswende als Modell religiöser Selbstbestimmung“. In: Dietmar Mieth, Regina Schiewer (eds.), Religiöse Selbstbestimmung, Anfänge im Spätmittelalter. Beiheft 7 zum Jahrbuch der Meister Eckhart Gesellschaft, Stuttgart: Kohlhammer.

- 2019: „Selftranscendence in Meister Eckhart“, in: Martin Fuchs et al. (eds.), Religious Individualisation: Historical Dimensions and Comparative Perspectives, Berlin: de Gruyter, 73-98.

\section{Müller-Schauenburg, Britta}

- 2013: Benedikt XIII., in K.-H. Braun et al. (eds.), Das Konstanzer Konzil. Essays, Theiss: Darmstadt, 121-125.

- 2013: Person, Sammlung, Kollektivität. Die Schutzmantelmadonna als Bild einer Versammlung mit spirituellem Gemeinschaftspunkt, in: G. Jähnert et al. (eds.), Kollektivität nach der Subjektkritik, Bielefeld: transcript, 197-219.

- 2014: Der Heilige Geist und das Ritual. Das Scheitern der Verhandlungen Sigismunds mit Pedro de Luna (Benedikt XIII.) 1415 in Perpignan, in: A. Büttner et al. (eds.), Grenzen des Rituals. Wirkreichweiten - Geltungsbereiche - Forschungsperspektiven, Köln: de Gruyter, 209-228.

- 2014: Erfolglos zu Recht schreiben. Die Pariser Handschriften des Traktats Quia nonulli Benedikts XIII. mit Britta Müller-Schauenburg, den Responsa, in: R. Berndt (ed.), Eure Namen sind im Buch des Lebens geschrieben. Antike und mittelalterliche Quellen als Grundlage moderner prosopographischer Forschung, (Erudiri Sapientia 11), Münster: Aschendorff, 381-412.

- 2017: Benedikts XIII. antihäretische Profilierung einer konservierten Einheitsfiktion - Die Handschrift BnF latin 1478 aus der Bibliothek des Papstes als Exempel, in: H. Müller (ed.), Der Verlust der Eindeutigkeit. Zur Krise päpstlicher Autorität im Kampf um die Cathedra Petri (Schriften des Historischen Kollegs. Kolloquien 95), Berlin: de Gruyter, 147-162.

- 2018: Einleitung, in R. Berndt (ed.), Der Papst und das Buch im Spätmittelalter (1350-1500). Bildungsvoraussetzung, Handschriftenherstellung, Bibliotheksgebrauch (Erudiri Sapientia 13), Münster: Aschendorff, 13-21.

- 2019: „The lonely antipope - or why we have difficulties classifying Pedro de Luna [Benedict XIII] as a religious individual“, in: Martin Fuchs et al. (eds.), Religious Individualisation: Historical Dimensions and Comparative Perspectives, Berlin: de Gruyter, 1351-1380.

- Forthcoming: Perpignan 1415. The negotiations and the role of Benedict XIII, in: A. Catafau et al. (eds.), Perpignan 1415. Ein europäisches Gipfeltreffen in der Konzilszeit/Perpignan 1415. Un sommet européen à l'époque des consiles.

\section{Mulder-Bakker, Anneke B.}

- 2019: Lived religion and eucharistic piety on the Meuse and the Rhine in the thirteenth and fourteenth centuries, in: Martin Fuchs et al. (eds.), Religious Individualisation: Historical Dimensions and Comparative Perspectives, Berlin: de Gruyter, 719-736. 


\section{Mulsow, Martin}

- 2012. Prekäres Wissen: Eine andere Ideengeschichte der Frühen Neuzeit. Berlin: Suhrkamp.

- 2015. Enlightenment underground: Radical Germany, 1680-1720, trans. H. C. Erik Midelfort (Studies in early modern German history). Charlottesville: University of Virginia Press.

-; Eskildsen, Kasper Risbjerg and Zedelmaier, Helmut (eds.). Christoph August Heumann (16811764): gelehrte Praxis zwischen christlichem Humanismus und Aufklärung (Gothaer Forschungen zur Frühen Neuzeit). Stuttgart: Steiner.

- 2012: „Joseph - Fracois Lafitau und die Entdeckung der Religions- und Kulturvergleiche”. In: Maria Effinger, Cornelia Logemann and Ulrich Pfisterer (eds.), Götterbilder und Götzendiener in der Frühen Neuzeit - Europas Blick auf fremde Religionen. Heidelberg: Universitätsverlag. 37-47.

- 2014. „The radical enlightenment: problems and perspectives”. In: Concepts of (radical) enlightenment: Jonathan Israel in discussion. Leipzig: Mitteldt. Verl. 81-94.

- 2014: „73. Eine Konversion zum Islam: Adam Neuser (ca. 1530-1576)”. In: Aus erster Hand: 95 Porträts zur Reformationsgeschichte: aus den Sammlungen der Forschungsbibliothek Gotha: Katalog zur Ausstellung der Universitäts- und Forschungsbibliothek Erfurt/Gotha vom 6. April bis 25. Mai 2014. Erfurt: Universität Erfurt. 146-7.

- 2015: „Vorwort“. In: Marten, Maria: Fogels Ordnungen: aus der Werkstatt des Hamburger Mediziners Martin Fogel (1634-1675). Frankfurt/M.: Klostermann. 11-2.

- 2015: „Vor Adam: Ideengeschichte jenseits der Eurozentrik“. Zeitschrift für Ideengeschichte: Marbach, Weimar, Wolfenbüttel, Grunewald 9 (1), 47-66.

- 2015: „Impartiality, individualisation, and the historiography of religion: Tobias Pfanner on the rituals of the ancient church". In: History and religion: narrating a religious past. Berlin: de Gruyter. 257-68.

- 2016: „Ökonomie des Wissens, Wissen der Ökonomie und Wissensökonomie.” In „Eigennutz“ und „gute Ordnung“: Ökonomisierungen der Welt im 17. Jahrhundert. Wiesbaden: Harrassowitz. 295-300.

- 2016: „Wissen am Hof: ,Gesamternestinische“ Gelehrte zwischen Weimar und Gotha um 1700.” Mens et Manus: Kunst und Wissenschaft an den Höfen der Ernestiner. Göttingen: Wallstein. 35-54.

- 2016: „Die Gothaer Illuminaten als fortgeführte ,gemeinnützige Privatgesellschaft‘? Die Aufsatzpraxis der Gothaer Sozietät von 1778 und die Minervalkirche von 1783-1787". In: Aufklärung: interdisziplinäres Jahrbuch zur Erforschung des 18. Jahrhunderts und seiner Wirkungsgeschichte 28, 343-60.

- 2017: „Hausenblasen: Kopierpraktiken und die Herstellung numismatischen Wissens um 1700.” In: Objekte als Quellen der historischen Kulturwissenschaften: Stand und Perspektiven der Forschung. Köln: Böhlau. 261-344.

- 2017: „Vincent Placcius: Freundschaftsethik, gemeinsame Forschung und moralphilosophische Lehre am Akademischen Gymnasium in Hamburg". In: Das Akademische Gymnasium zu Hamburg (gegr. 1613) im Kontext frühneuzeitlicher Wissenschafts- und Bildungsgeschichte. Berlin: de Gruyter. 87-101.

- 2017: „Der Verbesserer Heumanns Poecile im Kontext seiner Korrespondenz mit der Gelehrtenrepublik: Mit einem Inventar von Heumanns Briefwechsel”. In: Christoph August Heumann (1681-1764): gelehrte Praxis zwischen christlichem Humanismus und Aufklärung. Stuttgart: Steiner. 39-70.

- 2017: „Global intellectual history and the dynamics of religion”. In: Dynamics of religion: past and present: Proceedings of the XXI World Congress of the International Association for the History 
of Religions, Erfurt, August 23-29, 2015, edited by Christoph Bochinger and Jörg Rüpke; in cooperation with Elisabeth Begemann. Berlin: de Gruyter. 251-72.

-; Roling, Bernd 2016: „Wissenstransfer und Wissensverflechtungen: Wie Gelehrte der Frühen Neuzeit sich dem Orient näherten”. In: Engel, Christa (Hg.). Kulturen im Dialog: Das HERA-Förderprogramm „Cultural Encounters“Berlin: Bundesministerium für Bildung und Forschung, 32-3.

-; Linkenbach, Antje, 2019: „The Dividual Self: Introduction to Part 2“, in: Martin Fuchs et al. (eds.), Religious Individualisation: Historical Dimensions and Comparative Perspectives, Berlin: de Gruyter, 323-344.

- 2019: „Dividualisation and relational authorship: from the Huguenot République des lettres to practices of clandestine writing“, in: Martin Fuchs et al. (eds.), Religious Individualisation: Historical Dimensions and Comparative Perspectives, Berlin: de Gruyter, 475-496.

\section{Murphy, Anne}

- 2013. The Materiality of the Past: History and Representation in Sikh Tradition. New York: Oxford University Press, 2012; New Delhi: Oxford University Press, 2013.

- 2019: „Configuring community in colonial and pre-colonial imaginaries: Insights from the Khalsa Darbar records", in: Martin Fuchs and Vasudha Dalmia (eds.), Religious Interactions in Modern India. Delhi: Oxford University Press. doi:10.1093/oso/9780198081685.003.0006.

- 2019: „Sufis, Jogis, and the question of religious difference: Individualization in early modern Punjab“, in: Martin Fuchs et al. (eds.), Religious Individualisation: Historical Dimensions and Comparative Perspectives, Berlin: de Gruyter, 289-314.

\section{Nijhawan, Michael}

- 2016. The Precarious Diasporas of Sikh and Ahmadiyya Generations: Violence, Memory, Agency. New York: Palgrave Macmillan.

- 2013: „Lullabies for Broken Children: Diasporic Citizenship and the Dissenting Voices of Young Sikhs in Canada“, Co-authored with Kamal Arora, Sikh Formations: Religion, Culture, Theory 9(3), 299-322.

- 2014: „1984 and the Diasporic Politics of Aesthetics: Reconfigurations and New Constellations among Toronto Sikh Youth“, Diaspora: A Journal for Transnational Studies 17(2), 196-219.

- 2019: „Constructing a Genuine Religious Character: The Impact of the Asylum Court on the Ahmadiyya Minority in Germany“, in: Fuchs, M. et al. (eds.), Religious Individualisation: Historical Dimensions and Comparative Perspectives. Berlin: de Gruyter, 1139-1164.

- 2019: „Migrant Precarity and Religious Individualization“, in: Fuchs, M. et al. (eds.), Religious Individualisation: Historical Dimensions and Comparative Perspectives, Berlin: de Gruyter, 737-758.

\section{Otto, Bernd-Christian}

-; Michael Stausberg (eds.) 2013. Defining Magic. A Reader, [Critical Categories in the Study of Religion], Sheffield: Equinox.

-; Susanne Rau and Jörg Rüpke (eds.) 2015. History and Religion: Narrating a Religious Past, [Religionsgeschichtliche Versuche und Vorarbeiten; 68], Berlin: de Gruyter. 
-; Daniel Bellingradt 2017. Magical Manuscripts in Early Modern Europe. The Clandestine Trade in Illegal Book Collections, [New Directions in Book History], Basingstoke: Palgrave MacMillan. -; et al. (eds.) 2019. Religious Individualisation: Historical Dimensions and Comparative Perspectives. Berlin: de Gruyter.

- 2013: „Discourse theory trumps discourse theory: Wouter Hanegraaff's Esotericism and the Academy“, in Religion 43/2 (2013), 231-40.

-; Jörg Rüpke and Susanne Rau 2013: „Tagungsbericht: Historiography of Religion: New Approaches to origins of narrating a religious past“, in: H-Soz-u-Kult, 30.01.2013, online available at: http://hsozkult.geschichte.hu-berlin.de/tagungsberichte/id=4609-2013.

- 2013: „Towards historicizing 'Magic' in Antiquity“, in: Numen 60, 2/3 (2013), 308-47.

- 2013: „Zauberhaftes Ägypten - Ägyptischer Zauber? Überlegungen zur Verwendung des Magiebegriffs in der Ägyptologie“, in: Florian Jeserich (Hg.), Ägypten, Kindheit, Tod. Gedenkschrift für Edmund Hermsen, Wien, 39-70.

- 2015: „A Catholic ‘magician’ historicizes ‘magic’: Éliphas Lévi’s Histoire de la Magie“, in: Otto, Bernd-Christian et al. (eds.), History and Religion: Narrating a Religious Past, Berlin: de Gruyter, 419-43.

-; Susanne Rau and Jörg Rüpke 2015: „History and Religion“, in: Idd. (eds.), History and Religion: Narrating a Religious Past, Berlin: de Gruyter, 1-18.

- 2016: „Historicising 'Western learned magic': preliminary remarks“, in: Aries 16 (2016), 161-240.

- 2017: „Magic and Religious Individualization: On the construction and deconstruction of analytical categories in the Study of Religion“, in Historia Religionum 9 (2017), 29-52.

- 2018: „Das Motiv der Perfektionierung im gelehrtenmagischen Diskurs des 20. Jahrhunderts“, in: Thomas Bahne and Katharina Waldner (eds.), Die Perfektionierung des Menschen? Religiöse und ethische Perspektiven, [Vorlesungen des Interdisziplinären Forums Religion; 13], Münster: Aschendorff 2018. 81-105, 305-19.

- 2019: „A discourse historical approach towards medieval 'learned magic'“, in: Sophie Page and Catherine Rider (eds.), The Routledge History Handbook of Medieval Magic, London: Routledge 2018. 37-47, 60-64.

- 2019: „'Magie im Islam' aus diskursgeschichtlicher Perspektive“, in: Sebastian Günther and Dorothee Lauer (eds.), Die Geheimnisse der höheren und der niederen Welt: Magie im Islam zwischen Glaube und Wissenschaft, Leiden: Brill. 515-546.

- 2019: „If people believe in magic, isn't that just because they aren't educated?”, in: Wouter Hanegraaff, Marco Pasi, Peter Forshaw (eds.), Hermes Explains: Thirty-Five Questions about Western Esotericism. Celebrating the 20-year anniversary of the chair for History of Hermetic Philosophy and Related Currents at the University of Amsterdam, Amsterdam: Amsterdam University Press 2019. 198-206.

-; Parson, Rahul Bjørn 2019: „Introduction: conventions and contentions“, in Martin Fuchs et al. (eds.), Religious Individualisation: Historical Dimensions and Comparative Perspectives, Berlin: de Gruyter, 633-642.

- 2019: „The Illuminates of Thanateros and the Institutionalization of Religious Individualization“, in: Martin Fuchs et al. (eds.), Religious Individualisation: Historical Dimensions and Comparative Perspectives, Berlin: de Gruyter, 757-794.

- 2013: (Rev.) „Gideon Bohak, Yuval Harari, Shaul Shaked (eds.), Continuity and Innovation in the Magical Tradition", [Jerusalem Studies in Religion and Culture; 15], Leiden: Brill 2011, 396 pages, in ARIES: Journal for the Study of Western Esotericism 13/2 (2013), 308-13. 
- 2018: (Rev.) „Edward Bever, Randall Styers (eds.), Magic in the Modern World: Strategies of Repression and Legitimization", [The Magic in History Series], University Park: Pennsylvania University Press 2017, 207 pp., in Jahrbuch für Kommunikationsgeschichte 20 (2018).

- 2018: (Rev.) „Marco Frenschkowski, Magie im antiken Christentum. Eine Studie zur Alten Kirche und ihrem Umfeld“, [Standorte in Antike und Christentum; 7], Stuttgart: Hiersemann 2016, 338 S., in Zeitschrift für antikes Christentum 22/1 (2018).

\section{Parson, Rahul Bjørn}

- 2019: Individualisation and democratisation of knowledge in Banārasīdās' Samayasāra Nāțaka, in: Martin Fuchs et al. (eds.), Religious Individualisation: Historical Dimensions and Comparative Perspectives, Berlin: de Gruyter, 865-894.

-; Otto, Bernd-Christian 2019: Introduction: conventions and contentions, in: Martin Fuchs et al. (eds.), Religious Individualisation: Historical Dimensions and Comparative Perspectives, Berlin: de Gruyter, 633-642.

\section{Patera, loanna}

-; H. Bernier-Farella (eds.) 2014. L'objet rituel. Méthodes et concepts croisés = Special issue Revue d'histoire des religions 2014/4.

-; H. Bernier-Farella 2014: „L’objet rituel: concepts et méthodes croisés. Avant-propos“, Revue d'histoire des religions 2014/4, 531-538.

- 2015: „Objects as substitutes in ancient Greek ritual“, Religion in the Roman Empire 1.2, 181-200.

- 2019: „Individuals in the Eleusinian Mysteries: choices and actions“, in: Martin Fuchs et al. (eds.), Religious Individualisation: Historical Dimensions and Comparative Perspectives, Berlin: de Gruyter, 669-694.

\section{Quero-Sánchez, Andrés}

- 2019: ,Go from your country and your kindred and your father's house!' (Gen. 12:1): Schelling's Boehmian redefinition of idealism, in: Martin Fuchs et al. (eds.), Religious Individualisation: Historical Dimensions and Comparative Perspectives, Berlin: de Gruyter, 223-243.

\section{Raja, Rubina}

- 2019: Dining with the gods and the others: the banqueting tickets from Palmyra as expressions of religious individualisation, in: Martin Fuchs et al. (eds.), Religious Individualisation: Historical Dimensions and Comparative Perspectives, Berlin: de Gruyter, 243-256.

\section{Ramelli, Ilaria}

- 2013. The Christian Doctrine of Apokatastasis: A Critical Assessment from the New Testament to Eriugena, Leiden: Brill, Vigiliae Christianae Supplements 120. 
- (ed.). 2015. Tempo ed eternità in età antica e patristica: filosofia greca, ebraismo e cristianesimo, Assisi: Cittadella.

- (ed.) 2015. Early Christian and Jewish Narrative: The Role of Religion in Shaping Narrative Forms, edited by Ilaria Ramelli and Judith Perkins, Tübingen: Mohr Siebeck.

- (ed.) 2016. Social Justice and the Legitimacy of Slavery: The Role of Philosophical Asceticism from Ancient Judaism to Late Antiquity, Oxford: Oxford University Press.

-; Svetla S. Griffin (eds.) 2019. Lovers of Souls, Lovers of Bodies: Philosophical and Religious Perspectives in Late Antiquity. Cambridge, Mass.: Harvard University Press.

- 2014: „The Stoic Doctrine of Oikeiosis and its Transformation in Christian Platonism“, «Apeiron» 47 (2014), 116-140.

- 2015: „Ancient Jewish and Christian Exegeses of the ,Curse of Ham': Divergent Strategies against the Background of Ancient Views on Slavery“, in: David Nelson and Rivka Ulmer (eds.), ,It's better to hear the rebuke of the wise than the song of fools" (Qoh 7:5). Select Proceedings of the Midrash Section, Society of Biblical Literature, Volume 6, with Contributions by Ilaria Ramelli, Steven Sacks, Jonathan Kaplan, Piscataway: Gorgias, Series: Judaism in Context 18, 1-51.

- 2015: „Ethos and Logos: A Second-Century Apologetical Debate between „Pagan” and Christian Philosophers“, Vigiliae Christianae 69.2 (2015), 123-156.

- 2015: „Reply to Professor Michael McClymond“, Theological Studies 76.4 (2015), 827-835.

- 2017: „Origen and the Platonic Tradition“, Invited article, in: Plato and Christ: Platonism in Early Christian Theology, special topics issue of Religions, guest editor J. Warren Smith, Religions 2017, 8(2), 21, 1-20.

- 2017: „Divine Power in Origen of Alexandria: Sources and Aftermath“, in: Anna Marmodoro and Irini Fotini Viltanioti (eds.), Divine Powers in Late Antiquity, Oxford: OUP, 177-198.

- 2017: „Christian Apokatastasis and Zoroastrian Frashegird: The Birth of Eschatological Universalism“, Religion and Theology 24, 3-4 (2017), 350-406.

- 2018: „Origen to Evagrius“, in: Harold Tarrant, Dirk Baltzly, Danielle A. Layne, and François Renaud (eds.), Brill's Companion to the Reception of Plato in Antiquity, Leiden: Brill, 271-291.

- 2019: „Institutionalisation of Religious Individualisation: Asceticism in Antiquity and Late Antiquity and the Rejection of Slavery and Social Injustice“, in: Martin Fuchs et al. (eds.), Religious Individualisation: Historical Dimensions and Comparative Perspectives, Berlin: de Gruyter, 695-718.

\section{Reinhardt, Nicole}

- 2016. Voices of Conscience. Royal confessors and political counsel in seventeenth century Spain and France, Oxford: Oxford University Press.

- 2013: „Betrachtungen eines Unpolitischen? Überlegungen zur Geschichte der politischen Ideen im Kirchenstaat“", in: B. Emich and C. Wieland (ed.), Kulturgeschichte des Papsttums (Beiheft der Zeitschrift für historische Forschung 2013), 99-125.

- 2013: „Das königliche Gewissen im Prisma jansenistischer Kritik“, in: D. Burkard/T. Thanner (eds.), Der Jansenismus- eine 'katholische Häresie'? Das Ringen um Gnade, Rechtfertigung und die Autorität Augustins in der Neuzeit; Münster: Aschendorff, 349-73.

- 2014: „Introduction: War, Conscience, and Counsel in Early Modern Catholic Europe”, Journal of Early Modern History 18 (2014), 435-46.

- 2014: „Just War, Royal Conscience and the Crisis of Theological Counsel in the Early Seventeenth Century“, Journal of Early Modern History 18 (2014), 495-521. 
- 2015: „How individual was conscience in the early modern period? Observation on the development of Catholic moral theology“, Religion 45, no. 3 (2015), 409-28.

- 2017: „Hernando de Mendoça, General Acquaviva, and the Controversy over Confession, Counsel, and Obedience“, Journal of Jesuit Studies 4 (2017), 209-29.

\section{Renzi, Beatrice}

- 2015: „Anti-caste radicalism, Dalit movements and the many critiques of secular-nationalism in India“, in: M. Burchardt, M. Wohlrab-Sahr, M. Middell (eds.), Multiple Secularities Beyond the West: Religion and Modernity in the Global Age, Berlin: de Gruyter, 63-94.

\section{Rüpke, Jörg}

- 2013. De Júpiter a Cristo: Cambios religiosos en el Imperio Romano, Santa Maria: eduvim.

- 2013. Tra Giove e Christo: Trasformazioni religiose nell'impero romano, Trad. Roberto Alciati. Brescia: Morcelliana.

- 2014. From Jupiter to Christ: On the History of Religion in the Roman Imperial Period. Oxford:

Oxford University Press.

- 2014. Il crocevia del mito: Religione e narrazione nel mondo antico, Trad. Giovanni Cerro, Bologna: EDB.

- 2014. Religion: Antiquity and Modern Legacy, London/New York: Tauris/Oxford University Press.

- 2014. Römische Religion in republikanischer Zeit: Rationalisierung und ritueller Wandel, Darmstadt: Wissenschaftliche Buchgesellschaft, 2014.

- 2014. Superstitio: Devianza religiosa nell'Impero romano, Trad. Elisa Groff. Roma: Carocci.

- 2015. Superstition ou individualité ? Déviance religieuse dans l'Empire romain. Collection Latomus 352. Traduction par Ludivine Beaurin. Bruxelles/Leuven: Latomus/Peeters.

- 2016.On Roman Religion: Lived Religion and the Individual in Ancient Rome, Townsend Lectures. Ithaca, NY: Cornell University Press.

- 2016. Pantheon: Geschichte der antiken Religionen, Historische Bibliothek der Gerda-HenkelStiftung, München: Beck.

- 2016. Religious Deviance in the Roman World: Superstition or Individuality, Cambridge: Cambridge University Press.

- 2016. Superstición o individualidad. Desviaciones religiosas en el imperio romano. Trad. María Teresa, Josefina González, Micaela van Muylem. Madrid: UNED.

- 2018. Pantheon, trad. di Roberto Alciati, Maria dell'Isola, Biblioteca Einaudi, Torino: Einaudi.

- 2018. Pantheon: A New History of Roman Religion, trsl. by David M.B. Richardson, Princeton: Princeton University Press.

- 2018. Religiöse Transformationen im römischen Reich: Urbanisierung, Reichsbildung und SelbstBildung als Bausteine religiösen Wandels (Hans-Lietzmann-Vorlesung 16), Berlin: de Gruyter, 2018.

-; Wolfgang Spickermann (eds.) 2012. Reflections on Religious Individuality: Greco-Roman and Judaeo-Christian Texts and Practices (Religionsgeschichtliche Versuche und Vorarbeiten 62), Berlin/New York: de Gruyter.

-; Nicola Cusamano, Valentino Gasparini, Attilio Mastrocinque (eds.) 2013. Memory and Religious Experience in the Greco-Roman World (Potsdamer Altertumswissenschaftliche Beiträge 45). Stuttgart: Steiner. 
-; Bärbel Kracke, René Roux (eds.) 2013. Die Religion des Individuums (Vorlesungen des Interdisziplinären Forums Religion 9). Münster: Aschendorff

-; Martin Jehne, Bernhard Linke (eds.) 2013. Religiöse Vielfalt und soziale Integration: Die Bedeutung der Religion für die kulturelle Identität und politische Stabilität im republikanischen Italien. Studien zur Alten Geschichte 17. Heidelberg: Verlag Antike.

-; Greg Woolf (eds.) 2013. Religious Dimensions of the Self in the Second Century CE, Tübingen: Mohr Siebeck, 2013.

- (ed.) 2013. The Individual in the Religions of the Ancient Mediterranean, Oxford: Oxford University Press.

-; Raja, Rubina (eds.) 2015. A Companion to the Archaeology of Religion in the Ancient World. Boston: Wiley-Blackwell.

-; Eric Rebillard (eds.) 2015. Group Identity and Religious Individuality in Late Antiquity, CUA Studies in Early Christianity, Washington: Catholic University of America Press

-; Bernd-Christian Otto, Susanne Rau (eds.) 2015. History and Religion: Narrating a Religious Past. (Religionsgeschichtliche Versuche und Vorarbeiten 68). Berlin: de Gruyter.

-; Rubina Raja (eds.) 2015. Individual Appropriation in Lived Ancient Religion = Religion in the Roman Empire 1.1 (2015).

-; Christopher Degelmann (eds.) 2015. Narratives as a lens into lived ancient religion, individual agency and collective identity = Religion in the Roman Empire 1.3 (2015).

-; Clifford Ando (eds.) 2015. Public and Private in Ancient Mediterranean Law and Religion: A Historical and Comparative Conference. RGVV 65. Berlin: de Gruyter.

-; Martin Fuchs (eds.) 2015. Religious Individualization in Historical Perspective = Religion 45,1 (2015).

-; Christoph Bochinger (eds.) 2016. Dynamics of religion: Past and Present, Religionsgeschichtliche Versuche und Vorarbeiten 67, Berlin: de Gruyter.

- (ed.) 2015. The gods of the others = Archiv für Religionsgeschichte 15 (2014), 143-222.

-; Petridou, Georgia, Richard Gordon (eds.) 2017. Beyond Priesthood: Religious Entrepreneurs and Innovators in the Roman Empire, Religionsgeschichtliche Versuche und Vorarbeiten 65, Berlin: de Gruyter.

- (ed.) 2018. Construing religion(s) by historiography, = Archiv für Religionsgeschichte 20 (2018), $1-178$.

-; Marlis Arnhold, Harry O. Maier (eds.) 2018. Seeing the God: Image, Space, Performance and Vision in the Religion of the Roman Empire, Culture, Religion, and Politics in the Greco-Roman World 2, Tübingen: Mohr Siebeck.

- et al. (eds.) 2019. Religious Individualisation: Historical Dimensions and Comparative Perspectives. Berlin: de Gruyter.

- 2012: „Religion in der Antike“, in: Wolfgang Hameter, Sven Tost (Hgg.), Alte Geschichte: Der Vordere Orient und der mediterrane Raum vom 4. Jahrtausend v. Chr. bis zum 7. Jahrhundert $n$. Chr., vgs Studientexte 3, Wien: StudienVerlag, 283-300.

- 2013: „Archaic Roman Religion through the Republic“, in: Michele R. Salzman, Marvin A. Sweeney (eds.), Cambridge History of Religions in the Ancient World 1: From the bronze Age to the Hellenstic Age, Cambridge: University Press, 336-363.

- 2013: „Fighting for differences: Forms and limits of religious individuality in the ,Shepherd of Hermas'“, in: id. (ed.), Religious individuation in the Ancient Mediterranean, Oxford: Oxford University Press, 315-341.

- 2013: „Heiliger und öffentlicher Raum: Römische Perspektiven auf private Religion“, in: Babett Edelmann-Singer, Heinrich Konen (Hgg.), Salutationes: Beiträge zur Alten Geschichte und ihrer Diskussion. Festschrift Peter Herz zum 65. Geburtstag, Berlin: Frank \& Timme, 159-168. 
- 2013: „Individuals and Networks“, in: Corinne Bonnet, Laurent Bricault (eds.), Panthée: Religious Transformations in the Graeco-Roman Empire, (Religions in the Graeco-Roman World 177), Leiden: Brill, 261-277.

- 2013: „Individuelle Religion“, in: Alfred Schäfer, Marion Witteyer (Hgg.), Rituelle Deponierungen in Heiligtümern der hellenistisch-römischen Welt: Internationale Tagung Mainz 28.-30. April 2008, Mainz: Generaldirektion Kulturelles Erbe, 25-34.

-; Valentino Gasparini, Attilio Mastrocinque, Ennio Sanzi 2013: „Introduction“, in: idd. (eds.), Religious Memory and Experiences, PawB 45, Stuttgart: Steiner, 2013. 7-10.

- 2013: „Introduction: Individualisation and individuation as concepts for historical research“, in: Jörg Rüpke (ed.), Religious individuation in the Ancient Mediterranean, Oxford: Oxford University Press, 3-28.

- 2013: „On Religious Experiences That Should not Happen in Sanctuaries“, in: Valentino Gasparini, Attilio Mastrocinque, Jörg Rüpke, Ennio Sanzi (eds.), Religious Memory and Experiences, PawB 45, Stuttgart: Steiner, 137-144.

- 2013: „Polytheismus und Monotheismus als Perspektiven auf die antike Religionsgeschichte“, in: Christoph Schöbel (Hg.), Gott - Götter - Götzen: XIV. Europäischer Kongress für Theologie (11.-15. September 2011 in Zürich), Leipzig: Evangelische Verlagsanstalt, 56-68.

- 2013: „Regulating and Conceptualizing Religious Plurality: Italian Experiences and Roman Solutions“, in: Martin Jehne, Bernhard Linke, Jörg Rüpke (eds.), Religiöse Vielfalt und soziale Integration, 275-295.

-; Attilio Mastrocinque 2013: „Religious experience in the Roman World“, in: Valentino Gasparini, Attilio Mastrocinque, Jörg Rüpke, Ennio Sanzi (eds.), Religious Memory and Experiences, PawB 45, Stuttgart: Steiner, 135-136.

- 2013: „The others' god(s).“, Archiv für Religionsgeschichte 15 (2013), 245-248.

- 2013: „Two cities and one self: Transformations of Jerusalem and reflexive individuality in the Shepherd of Hermas“, in: id., Greg Woolf (eds.), Religious Dimensions of the Self in the Second Century CE, Tübingen: Mohr Siebeck, 49-65.

- 2013: „Überlegungen zur öffentlichen Festkultur aus ritualtheoretischer Perspektive“, in: Horst Groschopp (Hg.), Humanismus - Laizismus - Geschichtskultur (Schriftenreihe der Humanistischen Akademie Berlin 6), Aschaffenburg: Alibri Verlag, 123-138.

- 2013: „Was ist ein Heiligtum? Pluralität als Gegenstand der Religionswissenschaft“, in: Oliver Freiberger (Hg.), Alternative Voices: A Plurality Approach for Religious Studies. Essays in Honor of Ulrich Berner (Critical Studies in Religion/Religionswissenschaft 4). Göttingen: Vandenhoeck \& Ruprecht, 211-225.

- 2014: „Ethnicity in Roman Religion“, in: Jeremy McInerney (ed.), A Companion to Ethnicity in the Ancient Mediterranean, Boston: Wiley, 470-482.

- 2014: „Historians of religions and the space of law“, in: Salvo Randazzo (ed.), Religione e diritto Romano: la cogenza del rito, Tricase (LE): Libellula, 43-49.

- 2014: „Historicizing Religion: Varro's Antiquitates and History of Religion in the Late Roman Republic“, History of Religions 53.3 (2014), 246-268.

- 2014: „Im Rhythmus von Sonne und Mond: Die astronomischen und kulturellen Grundlagen der Zeitrechnung“, Welt und Umwelt der Bibel 19,4 (2014), 40-45.

- 2014: „Is history important for a historical argument in religious studies [Rev.article A. Norenzayah, Big Gods ... 2014] „, Religion 44,4 (2014), 645-648.

- 2014: „New Perspectives on Ancient Divination“, in: Veit Rosenberger (ed.), Divination in the Ancient World (Potsdamer altertumswissenschaftliche Beiträge 46), Stuttgart: Steiner, 9-19.

- 2014: „Religiöses Handeln: Kommunikation mit göttlichen Mächten“, in: Imperium der Götter: Isis - Mithras - Christus. Religionen im römischen Reich, hg. Badisches Landesmuseum, Stuttgart: Theiss, 32-39. 
- 2014: „Religiöse Individualität: Historische Befunde“, Jahrbuch der Meister-Eckehart-Gesellschaft 8 (2014), 1-9.

- 2015: „3.3. Religion: 3.3.1 Zentraler und westlicher Mittelmeerraum“, in: Anne-Maria Wittke (Hg.), Frühgeschichte der Mittelmeerkulturen: Historisch-archäologisches Handbuch (Der Neue Pauly Supplemente 10), Stuttgart: Metzler, 889-903.

-; Raja, Rubina 2015: „Archaeology of Religion, Material Religion, and the Ancient World“, in: Rubina Raja, Jörg Rüpke (eds.), A Companion to the Archaeology of Religion in the Ancient World, Malden: Wiley, 1-25.

-; Rubina Raja 2015: „Appropriating Religion: Methodological Issues in Testing the 'Lived Ancient Religion' Approach“, Religion in the Roman Empire 1.1 (2015), 11-19

- 2015: „Construing 'religion' by doing historiography: The historicisation of religion in the roman Republic“, in: Bernd-Christian Otto, Susanne Rau, Jörg Rüpke (eds.), History and Religion: Narrating a Religious Past, (Religionsgeschichtliche Versuche und Vorarbeiten 68), Berlin: de Gruyter, 45-62.

- 2015: „Das Imperium Romanum als religionsgeschichtlicher Raum“, in Richard Faber, Achim Lichtenberger (Hg.), Ein pluriverses Universum: Zivilisationen und Religionen im antiken Mittelmeerraum (Mittelmeerstudien 7), München: Fink, 333-351.

-; Christoph Bochinger 2015: „Dynamics of religion - past and present: Looking forward to the XXI World Congress of the IAHR“, in: Tim Jensen, Armin W. Geertz (eds.), Numen, The Academic Study of Religion and the IAHR: Past, Present, and Prospects, Leiden: Brill, 283-300.

-; et al. 2015: „Editorial“, Religion in the Roman Empire 1.1 (2015), 1-7.

- 2015: „Geteilte und umstrittene Geschichte: Der Chronograph von 354 und die Katakombe an der Via Latina“, in: Hartmut Leppin (Hg.), Antike Mythologie in christlichen Kontexten der Spätantike, Berlin: de Gruyter, 2015. 221-238.

-; Bernd-Christian Otto, Susanne Rau 2015: „History and Religion“, in: Bernd-Christian Otto, Susanne Rau, Jörg Rüpke (eds.), History and Religion: Narrating a Religious Past, (Religionsgeschichtliche Versuche und Vorarbeiten 68), Berlin: de Gruyter, 1-18.

- 2015: „Individual Choices and Individuality in the Archaeology of Ancient Religion.“, in: Rubina Raja, Jörg Rüpke (eds.), A Companion to the Archaeology of Religion in the Ancient World, Malden: Wiley, 437-450.

-; Clifford Ando 2015: „Introduction“, in: idd. (eds.), Public and Private in Ancient Mediterranean Law and Religion: An Historical and Comparative Conference. RGVV 65. Berlin: de Gruyter, 2015. 1-9.

-; Eric Rebillard 2015: „Introduction: Groups, Individuals, and Religious Identity“, in: Eric Rebillard, Jörg Rüpke (eds.), Group Identity and Religious Individuality in Late Antiquity, Catholic University of America Studies in Early Christianity, Washington: Catholic University of America Press, 2015. 3-12.

- 2015: with the assistance of Christopher Degelmann, „Narratives as a lens into lived ancient religion, individual agency and collective identity“, Religion in the Roman Empire 1.3 (2015), 289-296.

- 2015: „Öffentliche Festkultur und Ritual“, in: Doron Kiesel, Ronald Lutz (Hgg.), Religion und Politik: Analysen, Kontroversen, Fragen, Frankfurt/Main: Campus, 271-286.

-; Bernd-Christian Otto, Susanne Rau 2015: „Origins and Developments: Introduction“, in: BerndChristian Otto, Susanne Rau, Jörg Rüpke (eds.), History and Religion: Narrating a Religious Past, (Religions-geschichtliche Versuche und Vorarbeiten 68), Berlin: de Gruyter, 21-25.

-; Fuchs, Martin 2015: „Religion: Versuch einer Begriffsbestimmung“, in: Christoph Bultmann, Antje Linkenbach (eds.), Religionen übersetzen: Klischees und Vorurteile im Religionsdiskurs (Vorlesungen des Interdisziplinären Forums Religion der Universität Erfurt), Münster: Aschendorff, 17-22. 
- 2015: „Religione e guerra: Sulla relazione tra i sistemi politici e religiosi di una società“, in: Carlo Altini (ed.), Guerra e pace: Storia e teoria di un'esperienza filosofica e politica, Brescia: Il mulino, 53-81.

- 2015: „Religious agency, identity, and communication: reflections on history and theory of religion“, Religion 45.3 (2015), 344-366.

-; Martin Fuchs 2015: „Religious individualization in historical perspective“, Religion 45.3 (2015), 323-329.

- 2015: „Roles and Individuality in the Chronograph of 354“, in: Eric Rebillard, Jörg Rüpke (eds.), Group Identity and Religious Individuality in Late Antiquity, Catholic University of America Studies in Early Christianity, Washington: Catholic University of America Press, 247-269.

- 2015: „Roma imparatorlugu'nda dinî çogulculuk ve avrupa din tarihine etkileri“ [Religiöse Pluralität im Römischen Reich und ihre Folgen für die europäische Religionsgeschichte], Sabah Ülkesi 44 (2015), 18-21.

- 2015: „Rituelle Uniformität und religiöse Distinktion: Ein ritualtheoretischer Blick auf Altarweihungen“, in: Alexandra Busch, Alfred Schäfer (Hgg.), Römische Weihealtäre im Kontext, Friedberg: Likias, 2014 [2015], 19-25.

- 2015: „The ‘Connected Reader’ as a Window into Lived Ancient Religion: A Case Study of Ovid's Libri fastorum“, Religion in the Roman Empire 1.1 (2015), 95-113.

- 2015: „The role of priests in constructing the divine in ancient Rom“, in: Nicole Belayche, Vinciane Pirenne-Delforge (eds.), Fabriquer du divin: Constructions et ajustements de la représentation des dieux dans l'Antiquité, Collection Religions: Comparatisme - Histoire - Anthropologie 5, Liège: Presses Universitaires de Liège, 79-92.

-; Bernd-Christian Otto, Susanne Rau 2015: „Transforming narratives: Introduction“, in: BerndChristian Otto, Susanne Rau, Jörg Rüpke (eds.), History and Religion: Narrating a Religious Past, (Religionsgeschichtliche Versuche und Vorarbeiten 68), Berlin: de Gruyter, 327-331. 2016: „Ancient Lived Religion and the History of Religion in the Roman Empire“, Studia patristica 74 (2016), 1-20.

-; Bernd-Christian Otto, Susanne Rau 2015: „Writing histories: Introduction“, in: Bernd-Christian Otto, Susanne Rau, Jörg Rüpke (eds.), History and Religion: Narrating a Religious Past, (Religionsgeschichtliche Versuche und Vorarbeiten 68), Berlin: de Gruyter, 205-8.

- 2016: „Creating Groups and Individuals in Textual Practices“, Religion in the Roman Empire 2.1 (2016), 3-9. doi: 10.1628/219944616X14537295637718.

-; Casteigt, Julie, Mieth, Dietmar 2016: „Der Träger der Erfurter Riesenthorarolle: Eine religionsgeschichtliche Hypothese zu einem übersehenen Judaicum.", Zeitschrift für Religions- und Geistesgeschichte 68,2 (2016), 97-118.

- 2016: „Discourses and narratives, experiences and identities“, Religion in the Roman Empire 2.2 (2016), 149-151.

- 2016: „Divi Augusti oder: Wozu braucht man die neuen Götter?“, Latein und Griechisch in Berlin und Brandenburg 60.3 (2016), 46-51.

- 2016: „Erinnerung“, in: Daniel Weidner (Hg.), Handbuch Literatur und Religion, Stuttgart: Metzler, 28-33.

- 2016: „Historisierung von Religion“, in: Giovanni Casadio, Attilio Mastrocinque, Clauida Santi (eds.), Apex: Studi storico-religiosi in onore di Enrico Montanari, Roma: Quasar, 143-150. ISBN 978-88-7140-742-5

- 2016: „History and Theory“, Religion 46.3 (2016), 439-442.

- 2016: „Individual appropriation of sacred space“, in: Yves Lafonds, Vincent Michel (ed.), Espaces sacrés dans la Méditerranée antique, de l'âge du Bronze à l'Antiquité tardive, Rennes: Presses universitaires de Rennes, 69-80. 
- 2016: „Individualization and privatization“; in: Steven Engler, Michael Stausberg (eds.), The Oxford Handbook of the Study of Religion, New York: Oxford University Press, 702-717.

-; Christoph Bochinger 2016: „Introduction“, in: id. (eds.), Dynamics of Religion, RGVV 67, Berlin: de Gruyter, 1-8. doi: 10.1515/9783110450934-001.

- 2016: „Knowledge of religion in Valerius Maximus’ exempla: Roman historiography and Tiberian memory culture“, in: Karl Galinsky (ed.), Roman Memory, Oxford: Oxford University Press, 89-111.

-; Sylvie Estienne, Valentino Gasparini, Anne-Françoise Jaccottet 2016: „La religion romaine: une fabrique de la norme?", in: Tanja Itgenshorst (ed.), La norme sous la république et l'haut empire romains, Bordeaux: Ausonius, 201-216.

- 2016: „Starting sacrifice in the Beyond: Flavian innovations in the concept of priesthood and their repercussions in the treatise 'To the Hebrews'“, in: Gabriella Gelardini, Harold W. Attridge (eds.), Hebrews in Context, Ancient Judaism and Early Christianity 91, Leiden: Brill, 109-132.

- 2016: „Textgemeinschaften und die Erfindung von Toleranz in der römischen Kaiserzeit (2./3. Jh. n.Chr.)“, in: Martin Wallraff (Hg.), Religiöse Toleranz. 1700 Jahre nach dem Edikt von Mailand (Colloquium Rauricum 14), Berlin: de Gruyter, 141-157.

- 2016: „The Role of Texts in Processes of Religious Grouping during the Principate“, Religion in the Roman Empire 2.2 (2016), 170-195.

- 2016: „Warfare and ritual, Roman“, Encyclopedia of Ancient History, Malden: Wiley, online.

- 2016: „Warum es keine interreligiöse Beziehungen in der Antike gab“, in: Gabel, Michael, Malik, Jamal \& Okolowicz, Justyna (Hgg.), Religionen in Bewegung: Interreligiöse Beziehungen im Wandel der Zeit, VIFR 12. Münster: Aschendorff, 253-262.

-; Marlis Arnhold, Jörg Rüpke 2017: „Appropriating and Shaping Religious Practices in the Roman Republic“, in: Matthias Haake, Ann-Cathrin Harders (Hgg.), Polititsche Kultur und soziale Struktur der Römischen Republik: Bilanzen und Perspektiven, Stuttgart: Steiner, 413-427.

- 2017: „Cult and identity“, Politica antica 7 (2017), 121-137.

- 2017: „Doubling religion in the Augustan Age: Shaping time for an empire”, in: Jonathan Ben-Dov, Lutz Döring (eds.), The Construction of Time in Antiquity: Ritual, Art and Identity, Cambridge: Cambridge University Press, 2017. 50-68. 49.300 LZ.

- 2017: „Essen in religiösen Zusammenhängen im antiken Mittelmeerraum: Sakrale Mähler zwischen Euphrat und Tiber“, Welt und Umwelt der Bibel. 2017, 1. 32-39.

- 2017: „Etruskisches Denken in Zeitaltern“, in: Badisches Landesmuseum Karlsruhe (Hg.), Die Etrusker: Weltkultur im antiken Italien, Darmstadt: Theiss/Wissenschaftliche Buchgesellschaft, 337.

- 2017: „Georg Wissowa als Bearbeiter des ‘Sacralwesens'“, in: Kai Brodersen (Hg.), Joachim Marquardt, Georg Wissowa, Römische Staatsverwaltung 3, ND der 2. Aufl. 1885, Darmstadt: Wissenschaftliche Buchgesellschaft.

-; Paul Lichtermann, Rubina Raja, Anna-Katharina Rieger 2017: „Grouping together in lived ancient religion: individual interacting and the formation of groups", RRE 3.1 (2017), 3-10.

- 2017: „Der Hirte des Hermas: Visionsliteratur als Anleitung zu religiöser Praxis in Textproduktion und -rezeption“, in: Juan José Ferrer Maestro et al. (eds.), Entro los mundos: Homenaje a Pedro Barcelò/Zwischen den Welten: Festschrift für Pedro Barcelò, Besançon: Presses universitaires de Franche-Comté, 247-260.

-; Richard Gordon, Georgia Petridou 2017: „Introduction“, in: Richard Gordon, Georgia Petridou, Jörg Rüpke (eds.), Beyond Priesthood: Religious Entrepreneurs and Innovators in the Roman Empire, RGVV 66, Berlin: de Gruyter, 5-11.

- 2017: „Mut zur Religion“, Interjekte 10 (2017), 8-15. 
-; Federico Santangelo 2017: „Public priests and religious innovation in imperial Rome“, in Richard Gordon, Georgia Petridou, Jörg Rüpke (eds.), Beyond Priesthood: Religious Entrepreneurs and Innovators in the Roman Empire. RGVV 66, Berlin: de Gruyter, 15-47.

- 2017: „,Religion' as conceptualised in a Roman perspective“, Social Imaginaries 3.2 (2017), 37-56.

- 2017: „Römische Priestermähler“, in: David Hellholm et al. (eds.), Sacred Meal, Communal Meal, Table Fellowship, and the Eucharist, Wissenschaftliche Untersuchungen zum Neuen Testament. Tübingen: Mohr Siebeck, 1527-37.

- 2017: „Sukzessionen in römischen Priesterschaften“, in: Almut-Barbara Renger, Markus Witte (Hgg.), Sukzession in Religionen: Autorisierung, Legitimierung, Wissenstransfer, Berlin: de Gruyter, 375-391.

- 2018: „Caesar: Priesthoods, Gods, and Stars“, in: Luca Grillo, Christopher Krebs (eds.), Cambridge Companion to the Writings of Julius Caesar, Cambridge: University Press, 58-67. 2018: „Creating Religion(s) by Historiography“, ARG 20 (2018), 3-6.

- 2018: „Gifts, votives, and sacred things: Strategies, not entities“, RRE 4.2 (2018). 207-236.

-; Marlis Arnhold, Harry O. Maier 2018: „Introduction“, in: idd. (eds.), Seeing the God: Image, Space, Performance and Vision in the Religion of the Roman Empire, Culture, Religion, and Politics in the Greco-Roman World 2, Tübingen: Mohr Siebeck, vii-xix.

- 2018: „Not gods alone: On the visibility of religion and religious specialists in ancient Rome“, in: Marlis Arnhold, Harry 0. Maier, Jörg Rüpke (eds.), Seeing the God: Image, Space, Performance and Vision in the Religion of the Roman Empire, Culture, Religion, and Politics in the Greco-Roman World 2, Tübingen: Mohr Siebeck, 81-94.

- 2018: „Reflecting on Dealing with Religious Change“, RRE 4.2 (2018), 132-154.

- 2018: Janico Albrecht, Christoph Degelmann, Valentino Gasparini, Richard Gordon, Georgia Petridou, Rubina Raja, Jörg Rüpke, Benjamin Sippel, Emiliano Urciuoli, Lara Weiss, „Religion in the Making: The Lived Ancient Religion Approach“, Religion 48,4 (2018), 568-593.

- 2018: „Religious agency, sacralisation, and tradition in the ancient city”, Istrazivanya 29 (2018), 22-38. doi: 10.19090/i.2018.29.22-38

- 2019: „Narratives as factor and indicator of religious change in the Roman Empire (1st and 2nd centuries)“, Studia Patristica 99 (2019), 35-53.

- 2019: „Introduction: authorities in religious individualisation”, in: Martin Fuchs et al. (eds.), Religious Individualisation: Historical Dimensions and Comparative Perspectives, Berlin: de Gruyter, 971-981.

- 2019: „Ritual objects and religious communication in lived ancient religion: multiplying religion”, in: Martin Fuchs et al. (eds.), Religious Individualisation: Historical Dimensions and Comparative Perspectives, Berlin: de Gruyter, 1201-1222.

\section{Sander, Sabine}

- (ed.) 2015. Language as Bridge and Border: Linguistic, Cultural and Political Constellations in 18th to 20th Century German-Jewish Thought. Berlin: Hentrich \& Hentrich.

- 2017. Dialogische Verantwortung: Konzepte der Vermittlung und des Fremdverstehens im jüdischdeutschen Kontext des 19. und 20. Jahrhunderts, Paderborn: Fink.

- 2013: „Menschenrechte im Judentum“, in: Hamid Reza Yousefi (Hg.), Menschenrechte im Weltkontext. Geschichten - Erscheinungsformen - Neuere Entwicklungen, Wiesbaden: Springer 2013, S. 79-84. 
- 2015: „Between Acculturation and Self-Assertion. Individualization in the German-Jewish context of Prussia and the Weimar Republic and its Contribution to Culture and Social Theory of Modernity“, Religion. Journal of Religious Studies, vol. 45 (3) 2015, 429-450. doi: 10.1080/ 0048721X.2015.1024041.

- 2015: „Introduction. Language as a Border and a Bridge“, in: Sabine Sander (ed.), Language as Bridge and Border. Linguistic, Cultural and Political Constellations in 18th to 20th Century German-Jewish Thought, Berlin: Hentrich \& Hentrich, 11-30.

- 2015: „Messianic Universalism: The Social Ethics and Dialogue Philosophy of Hermann Cohen, Martin Buber, and Karl Löwith”, in: Sabine Sander (ed.), Language as Bridge and Border. Political, Cultural and Social Constellations in the German-Jewish context, Berlin: Hentrich \& Hentrich, 119-136.

- 2018: „Variations of the Embodied Self: George H. Mead, Ernst Cassirer, and Lawrence Krader on Human Being between Nature and Culture“, in: Cyril Levitt and Sabine Sander (ed.), Beyond the Juxtaposition of Nature and Culture: Lawrence Krader, Interdisciplinarity, and the Concept of the Human Being (Series: History and Philosophy of Science: Hersey, Crossroads, and Intersections, ed Paolo Palmieri), New York: Peter Lang, 99-130.

- 2019: „Jewish Emancipation, Religious Individualization, and Metropolitan Integration: A Case Study on Moses Mendelssohn and Moritz Lazarus“, in: Martin Fuchs et al. (eds.), Religious Individualisation: Historical Dimensions and Comparative Perspectives, Berlin: de Gruyter, 939-962.

\section{Sangari, Kumkum}

- 2019: Singular individuals, conflicting authorities: Annie Besant and Mohandas Gandhi, in: Martin Fuchs et al. (eds.), Religious Individualisation: Historical Dimensions and Comparative Perspectives, Berlin: de Gruyter, 1065-1096.

\section{Sangmeister, Dirk}

-2017. Vertrieben vom Feld der Literatur, Verbreitung und Unterdrückung der Werke von Friedrich Christian Laukhard. Bremen: edition lumière (= Presse und Geschichte, 104).

\section{Scheid, John}

- 2013. Les dieux, l'État et l'individu. Réflexions sur la religion civique à Rome, Paris, Seuil, 2013.

- 2015. The Gods, the State, and the Individual. Reflections on Civic Religion in Rome, Philadelphia: University of Pennsylvania Press, 2015.

- 2013: „Priests and prophets in Rome“, in: Dignas, B., Parker, R., Stroumsa, G. (éds.), Priests and Prophets among Pagans, Jews and Christians, Leuven: Peeters, 15-28.

- 2013: „Religion collective et religion privée”, Dialogues d'histoire ancienne, 39/2, 2013, 19-31.

- 2014: „Opferaltar und Weihaltar in Rom und in Italien“, in: Busch A. W., Schäfer A. (éds.), Römische Weihaltäre im Kontext (Tagung Köln 2009), Friedberg, 27-35.

- 2014: „I sacerdozi „arcaici” restaurati da Augusto. L’esempio degli arvali“, in: Urso G. (éd.), Sacerdos. Figure del sacro nella società romana, Cividale del Friuli, 26-28 settembre 2012, Pisa, (I convegni della Fondazione Niccolò Canussio 12) Edizioni ETS, 177-189. 
- 2015: „Auguste et la Religion“ in: Paolo Fedeli, Hans-Christian Günther (éds.), Augustus und Rom: 2000 Jahre danach, Rome, 19. 9. 2014 (Akten des Symposions, Studia Classica et Mediaevalia, vol. 9), Nordhausen 2015, 217-242.

- 2015: „Des dieux qui se fâchent mais ne connaissent pas le repentir. Le cas romain“, in: Durand J.-M., Marti L., Römer Th. (éds.), Colères et repentirs divins (Actes du colloque organisé les 24 et 25 avril 2013), Paris, 65-70.

- 2015: „Gaetano Marini et les frères arvales“, in: Gaetano Marini (1742-1815), Città del Vaticano 2015 (ST 492-493), 1187-1210.

- 2015: „Les Augustea et le culte des empereurs. Réflexions sur les rites célébrés dans ces lieux de culte“, in: P. Gros, E. Marin, M. Zink (éds.), Auguste, son époque et l'Augusteum de Narona, Paris: Académie des inscriptions et belles-lettres, 17-30.

- 2015: „Religious Practice un a World without Revelation: the Example of the Roman Empire“, in: Almqvist K., Linklater A., Religion. Perspectives from the Engelsberg seminar 2014, Stockholm, 45-52.

- 2015: „Spéculation érudite et religion. L'interaction entre l'érudition et les réformes religieuses à Rome“, in: Belayche N., Pirenne-Delforge, V. (éds.), Fabriquer du divin. Constructions et ajustements de la représentation des dieux dans l'Antiquité, Liège, 93-104.

- 2016: „Le lustrum et la lustratio. En finir avec la ,purification””, in: V. Gasparini (éd.), Vestigia. Miscellanea di studi storico-religiosi in onore di Filippo Coarelli nel suo 80 anniversario, Potsdamer Altertumswissenschaftliche Beiträge, vol. 55, Stuttgart, 203-209.

- 2016: „Moerae, Ilithyiae, Terra mater, des Grecques très romaines“, in: Bonnet C., Pirenne-Delforge V., Pironti G. (éds.), Dieux des Grecs, dieux des Romains. Panthéons en dialogue à travers l'histoire et l'historiographie, Bruxelles/Rome, 37-43.

\section{Scheuermann, Leif}

- 2013. Religion an der Grenze. Provinzialrömische Religion am Neckar- und äußeren obergermanischen Limes, Rahden/Westf.: Leidorf.

-; Spickermann, Wolfgang (eds.) 2013. Keltische Götternamen als individuelle Option? /Celtic Theonyms as an Individual Option?, Akten des 11. internationalen Workshops „Fontes Epigraphici Religionum Celticarum Antiquarum” vom 19.-21. Mai 2011 an der Universität Erfurt, Rahden/ Westf.: Leidorf.

\section{Schlette, Magnus}

- 2019: The inward sublime: Kant's aesthetics and the Protestant tradition, in: Martin Fuchs et al. (eds.), Religious Individualisation: Historical Dimensions and Comparative Perspectives, Berlin: de Gruyter, 99-140.

\section{Spickermann, Wolfgang}

- (ed.) 2013. Keltische Götternamen als individuelle Option? /Celtic Theonyms as an Individual Option?, Akten des 11. internationalen Workshops „Fontes Epigraphici Religionum Celticarum Antiquarum" vom 19.-21. Mai 2011 an der Universität Erfurt, Rahden/Westf.: Leidorf.

-; Scheuermann, Leif (eds.) 2016. Religiöse Praktiken in der Antike. Individuum, Gesellschaft, Weltbeziehung, Graz: Uni Press Graz. 
-; Waldner, Katharina; Gordon, Richard (eds.) 2016. Burial Rituals, Ideas of Afterlife, and the Individual in the Hellenistic World and the Roman Empire, Stuttgart: Steiner.

- 2013: „Kultisches und Religiöses bei Polybios“, in: V. Grieb/C. Koehn (Hrsg.) (Hg.): Polybios und seine Historien, Stuttgart: Steiner, 301-318.

- 2013: „Lucian of Samosata on Oracles, Magic and Superstition“, in: Veit Rosenberger (Hg.): Divination in the ancient world: religious options and the individual, Stuttgart: Steiner, 139-151.

- 2013: „Lukian von Samosata und die Leibesübungen“, in: P. Mauritsch/Chr. Ulf (Hrsg.) (Hg.), Kultur(en) - Formen des Alltäglichen in der Antike. Festschrift Ingomar Weiler zum 75. Geburtstag, Grazer Universitätsverlag Allgemeine wissenschaftliche Reihe 33, Nummi et Litterae VII, Bd. 2, Graz, 509-522.

- 2013: „Philosophical claim and individual lifestyles: Lucian's Peregrinus/Proteus - charlatan and Heros“, in: J. Rüpke/G. Woolf (Eds.) (Hg.): Religious Dimensions of the Self in the Second Century CE, Studien und Texte zu Antike und Christentum “ (STAC) 76, Tübingen, 175-191.

- 2013: „Women and the cult of Magna Mater in the Western provinces“, in: E. Hemelrijk/G. Woolf (eds.), Woman and the Roman City in the Latin West, Leiden, Boston: Brill, 147-168.

- 2014: „Arianische Vandalen, katholische Provinzialrömer und die Rolle kirchlicher Netzwerke im Nordafrika des 5. Jh. n.Chr“, in: Daniel Bauerfeld/Lukas Clemens (Hg.), Gesellschaftliche Umbrüche und soziale Netzwerke. Bielefeld: transcript, 65-86.

- 2014: „Kultplätze auf privatem Grund in den beiden Germanien“, in: Benedikt Kranemann/Christof Mandry/Hans-Friedrich Müller (eds.), Religion und Recht, Münster: Aschendorff, 167-196.

- 2014: „Neue epigraphische Zeugnisse gallo-römischer Götternamen aus den beiden Germanien“. in: Eck, Werner; Funke, Peter (eds.), Öffentlichkeit-Monument - TextXIV Congressus Internationalis Epigraphiae Graecae et Latinae 27.-31. Augusti MMXII Akten. Berlin: de Gruyter, 568-570.

- 2015: „Das Ende der Weiheinschriftenkultur in den beiden Germanien“, in: Lukas Clemens, Hiltrud Merten \& Christoph Schäfer (Hg.), Frühchristliche Grabinschriften im Westen des Römischen Reiches. Beiträge zur Internationalen Konferenz „Frühchristliche Grabinschriften im Westen des Römischen Reiches “, Trier, 13.-15. Juni 2013, Trier: Kliomedia, 75-85.

- 2015: „Eine Weihung an Mars Equitum aus Ravna, Serbien“, in: Sabine Panzram, Werner Riess und Christoph Schäfer (Hrsg.) (Hg.), Menschen und Orte in der Antike. Festschrift für Helmut Halfmann zum 65. Geburtstag, Rahden/Westf.: Leidorf, 257-272.

- 2015: „Lukian und die (Götter)bilder“, in: D. Boschung/A. Schäfer (Hg.), Römische Götterbilder der mittleren und späten Kaiserzeit, Paderborn: Fink, 87-107.

- 2015: „Monumental Inscriptions“, in: Rubina Raja/Jörg Rüpke (Hg.), A Companion to the Archaeology of Religion in the Ancient World, Chichester: Wiley Blackwell, 412-424.

- 2015: „Trauer und Tod in der 2. Sophistik am Beispiel des Lukian von Samosata“, in: Beate Ego, Ulrike Mittmann (Hg.), Evil and Death. Conceptions of the Human in Biblical, Early Jewish, Greco-Roman and Egyptian Literature, Berlin/Boston: de Gruyter, 275-293.

- 2016: „Regionale Zentren und „Stammes“heiligtümer in Nordgallien und Germanien“, in: Manfred Lehner/Bernhard Schrettle (Hg.), Zentralort und TempelbergSiedlungs- und Kultentwicklung amFrauenberg bei Leibnitz im VergleichAkten des Kolloquiums im Schloss Seggau am 4. und 5. Mai 2015, Wien: Phoibos, 197-209.

- 2016: „Tod und Jenseits bei Lukian von Samosata und Tatian“, in: Waldner, Katharina; Gordon, Richard; Spickermann, Wolfgang (Hg.), Burial Rituals, Ideas of Afterlife, and the Individual in the Hellenistic World and the Roman Empire, Stuttgart: Steiner, 67-81.

- 2017: „Inschriftlich bezeugte Stiftungen von Theatern und Kultgebäuden in Gallien und Germanien“, in: Thomas Hufschmid (Red) (Hg.), Theaterbauten als Teil monumentaler Heiligtümer in den nordwestlichen Provinzen des Imperium Romanum: Architektur - Organisation - Nutzung, Augusta Raurica, 37-47. 
- 2017: „Kulte, Religion und Heiligtümer in der Zeit des Marc Aurel“, in: Grieb, Volker (Hg.), Marc Aurel - Wege zu seiner Herrschaft, Gutenberg: Computus, 325-342.

- 2017: „Mogontiacum/Mainz als Zentrum der Romanisierung“, in: Claudia Horst/Tassilo Schmitt (Hg.), Die antike Stadt. Begriff - Imagination - Soziale Realität, Bremen: edition lumière, 79-112.

- 2017: „Religion in contact, Germany“, in: Roger S. Bagnall, Kai Brodersen, Craige B. Champion, Andrew Erskine (Hg.), The Encyclopedia of Ancient History (online), Chichester: Wiley, 1-3. doi:10.1002/9781444338386.wbeah3015

- 2017: „Überlegungen zum Kult der Magna Mater und des Attis im Westen des Imperium Romanum“, Carnuntum Jahrbuch 2016, 23-38.

\section{Stuckrad, Kocku von}

- 2015. The Scientification of Religion: An Historical Study of Discursive Change, 1800-2000, Berlin \& Boston: de Gruyter, Paperback edition published November 2015.

- 2013: „Discursive Study of Religion: Approaches, Definitions, Implications“, Method and Theory in the Study of Religion 25/1 (2013), 5-25.

- 2016: „Religion and Science in Transformation: On Discourse Communities, the Double-Bind of Discourse Research, and Theoretical Controversies“, in: Frans Wijsen \& Kocku von Stuckrad (eds.): Making Religion: Theory and Practice in the Discursive Study of Religion, Leiden \& Boston: Brill, 203-224.

\section{Suitner, Riccarda}

- (ed.) 2016. First Results of the Second Funding Period of the Research Group 'Religious Individualization in Historical Perspective'. A Reader, with Contributions by Martin Fuchs, Jörg Rüpke, Angelika Malinar, Rahul Parson, Richard L. Gordon, Dietmar Mieth, Bernd-Christian Otto, Nicole Reinhardt, Cristiana Facchini, Sabine Sander, Vera Höke, and Dorit Messlin, Erfurt.

- 2016: „Reformation, Medicine, and Religious Dissent in the Late Renaissance: the Case of the University of Padua“, in: Nuncius. Journal of the Material and Visual History of Science (XXXI), 2016, 11-31.

- 2017: „Radykalny reformator czy uczen Telesia? Przypadek Agostina Doniego“, in: Michat Choptiany and Piotr Wilczek (ed.), Reformacja w dawnej Rzeczypospolitej i jej europejskie konteksty. Postulaty badawcze [The Reformation in the Polish-Lithuanian Commonwealth and Its European Contexts: Research Proposals], Warsaw, Wydawnictwa Uniwersytetu Warszawskiego: Warsaw University Press, 123-142.

- 2019: „Reformation, Naturalism and Telesian Philosophy: the Case of Agostino Doni“, in: Pietro Daniel Omodeo (ed.), Bernardino Telesio and the Natural Sciences in the Renaissance, Leiden: Brill.

- 2019: „The Good Citizen and the Heterodox Self: Turning to Protestantism and Anabaptism in Sixteenth-Century Venice“, in: Martin Fuchs et al. (eds.), Religious Individualisation: Historical Dimensions and Comparative Perspectives, Berlin: de Gruyter, 459-474. 


\section{van Hove, Rebecca}

- 2019: „A Dream on Trial: The Contest of Oracular Interpretations and Authorities in Hyperides 'In Defence of Euxenippus'“, Mnemosyne 72, 405-36.

\section{Vannier, Marie-Anne}

- 2015. Cheminer avec maître Eckhart. Au cœur de l'anthropologie chrétienne, Paris: Artège.

- (ed.) 2013. La christologie chez Eckhart et Nicolas de Cues, Paris: Cerf, coll. «Patrimoines».

- (ed.) 2014 Intellect, sujet, image chez Eckhart et Nicolas de Cues, Paris: Cerf.

-; H. Schwaetzer (eds.) 2015. Der Bildbegriff bei Meister Eckhart und Nikolaus von Kues, Münster: Aschendorff.

- (ed.) 2015. Maître Eckhart, Commentaire du Livre de la Sagesse, Introduction, notes, Paris: Les Belles Lettres.

-; D. Mieth, M. Vinzent, C.M. Wojtulewicz (eds.) 2016. Meister Eckhart in Paris and Strasbourg, Leuven: Peeters.

- (ed.) 2017, Mystique rhénane et Devotio moderna, Paris: Beauchesne, coll. «Mystiques d’Orient et d'Occident».

- 2013: „La christologie d'Eckhart: une réalité à redécouvrir“, in: M.-A. Vannier (dir.), La christologie chez Eckhart et Nicolas de Cues, Pars: Cerf, coll. «Patrimoines», 9-15.

- 2013: „L'Un et la relation chez Eckhart“, in: R. Cazalis (éd.), Monade, Dyade, Triade. Des approches de la réalité, Namur: Presses Universitaires de Namur, 59-75.

- 2014: „Sujet, intellect, image chez Eckhart“, in: Intellect, sujet, image chez Eckhart et Nicolas de Cues, Paris: Cerf, 17-39.

- 2015: „Die Bedeutung der Frage des Bildes bei den Rheinischen Mystikern“, in: H. Schwaetzer, M.-A. Vannier, Der Bildbegriff bei Meister Eckhart und Nikolaus von Kues, Münster: Aschendorff, 9-17.

- 2015: „Eckhart, lecteur d'Origène“, Irénikon LXXXVIII (2015), 483-496.

- 2015: „L'expérience mystique chez Eckhart“, in: D. Cohen-Levinas, G. Roux, M. Sebti, Mystique et philosophie dans les trois monothéismes, Paris: Hermann, 91-108.

- 2015: „L'originalité de l'interprétation eckhartienne des Noces de Cana“, in: J.-M. Vercruysse, Les Noces de Cana, Arras: Graphè, 103-113.

- 2016: „Eckhart et Augustin“, Théophilyon XXI (2016), 39-52.

- 2016: „Eckhart, une lecture de Genèse 1, 1“, in: B. Bakhouche (éd.), Science et exégèse. Les interprétations antiques et médiévales du récit biblique de la création des éléments (Gn 1,1-8), Turnhout: Brepols, BEHE, 347-354.

- 2016: „L'humilité“, in: ead. (éd.), L'humilité chez les mystiques rhénans et Nicolas de Cues, Paris, Beauchesne, 7-15.

- 2017: „D’Erfurt à Strasbourg. L'arrivée d'Eckhart à Strasbourg, il y a 700 ans“, D. Mieth, M.-A. Vannier, M. Vinzent, C. Wojtulewicz, Meister Eckhart in Paris and Strasbourg, Leuven, Peeters, 325-334.

- 2017: „Eckhart or the actuality of a classic“, in: P. Cooper, S. Kikuchi S. (ed.), Commitments to Medieval Mysticism within Contemporary Contexts, Leuven: Peeters, Bibliotheca Ephemeridum Theologicarum Lovaniensium, 290, 177-194.

- 2017: „Introduction“, in: D. Mieth, M.-A. Vannier, M. Vinzent, C. Wojtulewicz, Meister Eckhart in Paris and Strasbourg, Leuven, Peeters, XI-XXII. 
- 2017: „Les rapports entre la mystique rhénane et la Devotio moderna“, ead. (éd.), Mystique rhénane et Devotio moderna, Paris: Beauchesne, 13-19.

- 2017: „L'écriture d'Eckhart. L'exemple de sa théologie trinitaire“, in: E. Boncour, P. Gire, E. Mangin, Maître Eckhart, une écriture inachevée, Grenoble: Jérôme Millon, 125-133.

- 2017: „L'essor des études eckhartiennes en France“, D. Mieth, ead., M. Vinzent, C. Wojtulewicz, Meister Eckhart in Paris and Strasbourg, Leuven, Peeters, 157-175.

- 2017: „Présentation“, D. Mieth, M.-A. Vannier, M. Vinzent, C. Wojtulewicz, Meister Eckhart in Paris and Strasbourg, Leuven, Peeters, 321-322.

- 2017: „Présentation de Mystique rhénane et Devotio moderna“, in: ead. (éd.), Mystique rhénane et Devotio moderna, Paris: Beauchesne, 11-12.

- 2018: „Der Freie Geist/Das ledige Gemüt bei Meister Eckhart“, in: Meister-Eckhart-Jahrbuch 12 (2018), 201-212.

- 2018: „Origen, a Source of Meister Eckhart’s Thinking“, in: M. Vinzent, Studia Patristiica. Vol. XCVII - Papers presented at the Seventeenth International Conference on Patristic Studies held in Oxford 2015 Volume 23: From the Fourth Century Onwards (Latin Writers), Nachleben, Leuven: Peteers, 345-354.

\section{Vinzent, Jutta}

- 2013: „Challenging the abstract in late 1930s Britain“, in: Jordana Mendelson (ed.), Encounters with the 1930s, exhibition catalogue, Museo Nacional Centro de Arte Reina Sofía, Madrid, 3 October 2012-7 January 2013 (ISBN 978-84-15691-01-3), 140-147.

- 2016: „Austria in Die Zeitung: The Instrumentalisation of Émigré Newspapers during WWII and the Subversive Power of Cartoons“, in: Mark Stocker and Phillip G. Lindley (eds.), Tributes to Jean Michel Massing. Towards a Global Art History, London: Harvey Miller, 323-343.

- 2016: „Space and Form in String Sculptures: Naum Gabo, Barbara Hepworth and Henry Moore“, in: Hans Aurenhammer and Regine Prange (eds.), Das Problem der Form. Interferenzen zwischen moderner Kunst und Kunstwissenschaft, Berlin: Gebrüder Mann Verlag, (Neue Frankfurter Forschungen zur Kunst, 18), 355-381.

- 2016: „Space, Time and Body in Performance Art and Meister Eckhart“, in: ead., Christopher M. Wojtulewicz (eds.), Performing Bodies. Time and Space in Meister Eckhart and Taery Kim, Leuven: Peeters, 2016 (Eckhart: Texts and Studies, 6), 217-265.

- 2017: ,in conversation with Tim Ingold 2017, 'Representations on the line. From lines as geometrical form to lines as meshwork rather than network", in: Sebastian Dorsch and Jutta Vinzent (eds.), SpatioTemporalities on the Line. Representations - Practices - Dynamics, Berlin/ Boston: de Gruyter, (SpatioTemporality. Practices - Concepts - Media, 3), 13-19.

- 2019: „Challenging Personhood. The Subject and Viewer of Contemporary Crucifxion Iconography“, in Martin Fuchs et al. (eds.), Religious Individualisation: Historical Dimensions and Comparative Perspectives, Berlin: de Gruyter, 603-624.

\section{Vinzent, Markus}

- 2019: Monism and dividualism in Meister Eckhart, in Martin Fuchs et al. (eds.), Religious Individualisation: Historical Dimensions and Comparative Perspectives, Berlin: de Gruyter, 363-382. 


\section{von Wyss-Giacosa, Paola}

-; Isler, Andreas (eds.) 2017. Gemachte Bilder. Derwische als Orient-Chiffre und Faszinosum, Zürich: VMZ.

- 2013: „Henri Michaux und die Idolatrie Indiens“, in: Schwarz, Dieter (ed.), Henri Michaux, Momente, Düsseldorf: Richter, 26-33

- 2014: „Confronting Asia's ,Idolatrous Body’, Reading some Early Modern European Sources on Indian Religion“, in: Höpflinger, Anna-K./Ornella, Alexander D./Knauss, Stefanie (eds.), Commun(icat)ing Bodies, Body as a Medium in Religious Systems, Zürich/Baden-Baden: Pano/Nomos, 387-423.

- 2015: „Western imaginaries between fascination, colonial construction and appropriation. The Lore of a Mysterious India, of Kali, the Black Goddess, and of her Evil Devotees“, in: PezzoliOlgiati, Daria (ed.), Religion in Cultural Imaginary. Explorations in Visual and Material Practices, Religion - Wirtschaft - Politik, Vol. 13, Zürich/Baden-Baden: Pano/Nomos, 79-115.

- 2017: ,Ein thailändischer Buddha in Gottorf. Zur Bedeutung materieller Zeugnisse im frühneuzeitlichen Idolatrie-Diskurs“, in: Cremer, Annette Caroline/Mulsow, Martin (eds.), Objekte als Quellen der historischen Kulturwissenschaften. Stand und Perspektive der Forschung, Wien: Böhlau-Verlag, 211-224.

- 2017: „Gemachte Bilder. Einige Beobachtungen zur visuellen Repräsentation des „Derwischs“ in europäischen Berichten seit der frühen Neuzeit“, in: von Wyss-Giacosa, Paola/Isler, Andreas (eds.), Gemachte Bilder. Derwische als Orient-Chiffre und Faszinosum, Zürich: VMZ, 49-100.

\section{Wildberger, Jula}

- 2019: „Cosmic Beauty in Stoicism: A Foundation for an Environmental Ethic as Love of the Other?", in: Hunt, Ailsa/Marlow, Hilary (eds.), Ecology and Theology in the Ancient World: Cross-Disciplinary Perspectives, London: Bloomsbury, 63-74.

\section{Woolf, Greg}

-; Hemelrijk, E. (eds.) 2013. Women and the Roman City in the Latin West, (Mnemosyne Supplements). Leiden: Brill.

-; Rüpke, J. (eds.) (2013). Religious Dimensions of the Self in the Second Century CE. (Studien und Texte zu Antike und Christentum; 76). Stuttgart: Mohr Siebeck.

- 2013: „Female Mobility in the Latin West“, in: Hemelrijk, Emily \& Greg Woolf (eds.), Women and the Roman City in the Latin West, (Mnemosyne, Supplements, History and Archaeology of Classical Antiquity), Leiden: Brill, 351-368.

- 2013: „Ritual and the Individual in Roman Religion“, in: Rüpke, J. (ed.), The Individual in the Religions of the Ancient Mediterranean, Oxford: Oxford University Press, 136-160.

- 2014: „Isis and the evolution of religions“, in: Bricault, L., \& Versluys, M. J. (eds.), Power, Politics, and the Cults of Isis, (Religions of the Graeco-Roman World), Leiden: E. J. Brill, 62-92.

- 2015: „Mars and memory“, in: K. Galinsky and K. Lapatin (eds.), Cultural memories in the Roman Empire, Los Angeles: Getty Publications, 206-224.

- 2015: „Ritual Traditions of Non-Mediterranean Europe“. In: Raja, R., \& Rüpke, J. (eds.), A Companion to the Archaeology of Religion in the Ancient World, Wiley-Blackwell, 465-477. 
- 2016: „Only Connect? Network Analysis and Religious Change in the Roman World“ in: Cláudia Beltrão (ed.), Revista Hélade de História Antiga 2.2, Religiões no Mundo Antigo, 43-58.

- 2016: „Polis religion“, in: Orlin, E. (ed.), The Routledge Encyclopedia of Ancient Mediterranean Religions, Routledge.

- 2017: „Empires, diasporas and the emergence of religions“, in: J. Carleton-Paget and J. Lieu (eds.), Christianity in the Second Century. Themes and Developments, Cambridge University Press: New York, 25-38.

\section{Zwierlein, Cornel}

-; Vincenzo Lavenia (eds.) 2018. The Fruits of Migration. Heterodox Italian Migrants and Central Europe - 1550-1620, Leiden: Brill (Intersections Nr. 57).

- 2017: „,Konfessionalisierung“ europäisch, global als epistemischer Prozess: Zu den Folgen der Reformation und zur Methodendiskussion“, in: Christoph Strohm (Hg.): Reformation und Recht. Zur Kontroverse um die Kulturwirkungen der Reformation, Tübingen: Mohr Siebeck, $1-51$.

- 2017: „Herrschaft und Reziprozität: Vom Sichtbarwerden der Gegenseitigkeit in Krieg und Konflikt (Paris-Rom 1589)“, in: Zeitschrift der Savigny-Stiftung für Rechtsgeschichte. Germanistische Abteilung 134 (2017), 71-98.

- 2018: „Historicizing Environmental Security“, in European Journal of Security Research 3 (2018), 1-13.

- 2018: „Security, Nature and Mercantilism in the Early British Empire“, in European Journal of Security Research 3 (2018), 15-34.

- 2018: „Tyrannenmord, Majestätsverbrechen und Herrscherwechsel bei Shakespeare: Resonanzen konfessioneller Polarisierung um 1600“, in Shakespeare-Jahrbuch 154 (2018), 31-53. 